\title{
Literature Review: Strategic Network Optimization Models in Waste Reverse Supply Chains - Online Appendix
}

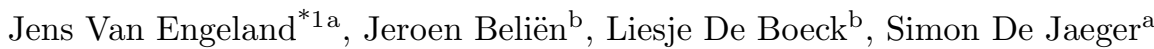

${ }^{a}$ KU Leuven, Center for Economics and Corporate Sustainability, Faculty of Economics and Business, Campus Brussels, Warmoesberg 26, BE-1000 Brussels, Belgium

${ }^{b}$ KU Leuven, Research Center for Quantitative Business Processes, Faculty of Economics and Business, Campus Brussels, Warmoesberg 26, BE-1000 Brussels, Belgium

*corresponding author, address: Warmoesberg 26, BE-1000 Brussels.

Email addresses: jens.vanengeland@kuleuven.be

(Jens Van Engeland ${ }^{* 1}$ ), jeroen.belien@kuleuven.be

(Jeroen Beliën), liesje.deboeck@kuleuven.be (Liesje De Boeck),

simon.dejaeger@kuleuven.be (Simon De Jaeger)

${ }^{1}$ supported by a Ph. D. fellowship of the Research Foundation -

Flanders (FWO) 
Table A.1: Network type of reviewed papers. Reuse and repair refer generally to the final product level. Refurbished products or parts needed clean up, a new layer of paint and/or reparation. The remanufacturing process might provide a product with new parts. Recovery at the materials level is classified as recycling. Treatment indicates whether the stream of products is subjected to a procedure before final disposal, for example thermal treatment. Some models do only model part of a network, or do not specify the recovery option. These models are classified as "not specified/general".

\begin{tabular}{|c|c|c|c|c|c|c|c|c|c|c|c|}
\hline \multirow{9}{*}{ open loop } & \multirow{2}{*}{$\begin{array}{l}\text { recovery option } \\
\text { reuse }\end{array}$} & \multirow[t]{2}{*}{$1995-1998$} & \multirow[t]{2}{*}{ 1999-2002 } & \multirow[t]{2}{*}{ 2003-2006 } & \multirow{2}{*}{$\begin{array}{l}2007-2009 \\
{[71]}\end{array}$} & \multicolumn{2}{|c|}{$2010-2012$} & \multirow{2}{*}{\multicolumn{2}{|c|}{$\frac{2013-2015}{[201],[67]}$}} & \multicolumn{2}{|l|}{ 2016-2017 } \\
\hline & & & & & & & & & & \multicolumn{2}{|l|}{$[104],[214]$} \\
\hline & repair & & & & [71] & & & [213] & & {$[104],[215],[76$} & \\
\hline & refurbish & & & & [71] & & & {$[230],[208]$} & & {$[215]$} & \\
\hline & remanufacture & & {$[280]$} & & & $\begin{array}{l}{[163],} \\
{[79]}\end{array}$ & [83], & {$[238],[230],[213$} & & $\begin{array}{l}{[86], \quad[222],} \\
{[215], \quad[243],} \\
{[76],[105]}\end{array}$ & {$[104]$,} \\
\hline & recycling & {$[174],[88]$} & $\begin{array}{l}{[188],} \\
{[189]}\end{array}$ & {$[89],[259]$} & $\begin{array}{l}{[156], \quad[281],} \\
{[94],[71]}\end{array}$ & $\begin{array}{l}{[129],} \\
{[163],} \\
{[122],} \\
{[178],} \\
{[112]}\end{array}$ & $\begin{array}{l}{[282],} \\
{[138],} \\
{[83],} \\
{[79],}\end{array}$ & $\begin{array}{ll}{[283],} & {[236],} \\
{[101],} & {[135],} \\
{[245],} & {[113],} \\
{[213],} & {[165],} \\
{[118],} & {[130],} \\
{[255],} & {[208],} \\
{[160],} & {[95]}\end{array}$ & $\begin{array}{l}{[201],} \\
{[258],} \\
{[238],} \\
{[98],} \\
{[199],} \\
{[114],}\end{array}$ & $\begin{array}{lc}{[86],} & {[103],} \\
{[214],} & {[284],} \\
{[127],} & {[285],} \\
{[260],} & {[207],}\end{array}$ & $\begin{array}{l}{[104],} \\
{[151],} \\
{[76],} \\
7]\end{array}$ \\
\hline & (thermal) treatment & {$[174]$} & & & [99] & {$[129],[1$} & 00], & {$[101],[102],[114$} & & $\begin{array}{ll}{[103],} & {[104],} \\
{[149],} & {[286],} \\
{[285]} & \end{array}$ & {$[284]$,} \\
\hline & final disposal & {$[174]$} & {$[287]$} & [195] & {$[196]$} & $\begin{array}{l}\text { [129], } \\
{[83],} \\
{[79],[28}\end{array}$ & $\begin{array}{l}{[100],} \\
{[288],} \\
9]\end{array}$ & $\begin{array}{ll}{[283],} & {[201],} \\
{[113],} & {[213],} \\
{[199],} & {[208],} \\
{[160],} & {[119]}\end{array}$ & $\begin{array}{l}{[101]} \\
{[130]} \\
{[114]}\end{array}$ & $\begin{array}{l}{[86], \quad[103],} \\
{[104],} \\
{[149],} \\
{[214],} \\
{[285],} \\
{[290],} \\
{[263]}\end{array}$ & $\begin{array}{l}{[222],} \\
{[284],} \\
{[215],} \\
{[207],}\end{array}$ \\
\hline & not specified/general & & & & {$[246],[233]$} & {$[139],[2$} & 89] & $\begin{array}{l}{[235], \quad[191],} \\
{[237],[231],[171}\end{array}$ & [291], & $\begin{array}{l}{[248], \quad[180],} \\
{[134],[181]}\end{array}$ & {$[126]$,} \\
\hline \multirow[t]{7}{*}{ closed loop } & reuse & & & & & & & {$[64],[65],[66],[$} & [292] & {$[261],[293],[69$} & ], [68] \\
\hline & repair & & & [70] & & [294] & & $\begin{array}{ll}{[183],} & {[202],}\end{array}$ & {$[266]$} & $\begin{array}{ll}{[261],} & {[72],} \\
{[240],} & {[148],} \\
{[75],} & {[192],} \\
{[153]} & \end{array}$ & $\begin{array}{r}{[73],} \\
{[74],} \\
{[186],}\end{array}$ \\
\hline & refurbish & & & & & & & $\begin{array}{l}{[197], \quad[159],} \\
{[212], \quad[184],} \\
{[65],[77],[172],}\end{array}$ & $\begin{array}{l}{[228]} \\
{[202]} \\
{[173]}\end{array}$ & $\begin{array}{l}{[145],[78],[69]} \\
{[192]}\end{array}$ & , [75], \\
\hline & remanufacture & & & {$[70],[136]$} & {$[108]$} & $\begin{array}{l}{[15],} \\
{[234],} \\
{[295],} \\
{[168],} \\
{[223],} \\
{[242]}\end{array}$ & $\begin{array}{l}{[190],} \\
{[203],} \\
{[294],} \\
{[84],} \\
{[158],}\end{array}$ & 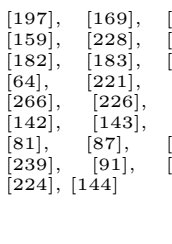 & $\begin{array}{r}{[227],} \\
{[2212],} \\
{[184],} \\
{[65],} \\
{[77],} \\
{[15],} \\
{[166],} \\
{[131],}\end{array}$ & $\begin{array}{ll}{[194],} & {[124],} \\
{[209],} & {[146],} \\
{[211],} & {[161],} \\
{[204],} & {[193],} \\
{[216],} & {[73],} \\
{[162],} & {[262],} \\
{[120],} & {[296],} \\
{[297],} & {[298],} \\
{[219],} & {[217],} \\
{[241],} & {[186],} \\
{[153]} & \end{array}$ & $\begin{array}{l}{[145],} \\
{[78],} \\
{[125],} \\
{[154],} \\
{[210],} \\
{[148],} \\
{[82],} \\
{[167],} \\
{[220],} \\
{[128],}\end{array}$ \\
\hline & (thermal) treatment & {$[106]$} & & & & & & & & & \\
\hline & final disposal & & & [70] & [93] & $\begin{array}{l}{[157],} \\
{[15],} \\
{[294],} \\
{[223],} \\
{[158]}\end{array}$ & $\begin{array}{l}{[225],} \\
{[203],} \\
{[84],} \\
{[200],}\end{array}$ & 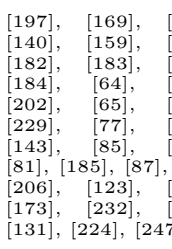 & $\begin{array}{l}{[227],} \\
{[228],} \\
{[244],} \\
{[221],} \\
{[266],} \\
{[142],} \\
{[170],} \\
,[66], \\
{[172],} \\
{[239],} \\
7]\end{array}$ & $\begin{array}{lc}{[124],} & {[145],} \\
{[78],} & {[211],} \\
{[204],} & {[193],} \\
{[216],} & {[73],} \\
{[162],} & {[148],} \\
{[69],} & {[75],} \\
{[121],} & {[219],} \\
{[68],} & {[152],[153}\end{array}$ & $\begin{array}{l}{[146],} \\
{[161],} \\
{[154],} \\
{[210],} \\
{[74],} \\
{[133],} \\
{[192],}\end{array}$ \\
\hline & not specified/general & & & & [109] & & & $\begin{array}{l}{[164], \quad[301],} \\
{[185], \quad[206],} \\
{[232],} \\
{[247]}\end{array}$ & $\begin{array}{l}{[141],} \\
{[123],}\end{array}$ & [249] & \\
\hline
\end{tabular}


Table A.2: Overview of models with a single objective. NIMBY = Not In My BackYard, characterizing opposition of affected residents. The "min. cost / max. revenue" objective represents cost (revenue) in general terms: total cost, total discounted cost, cost per product returned, etc.

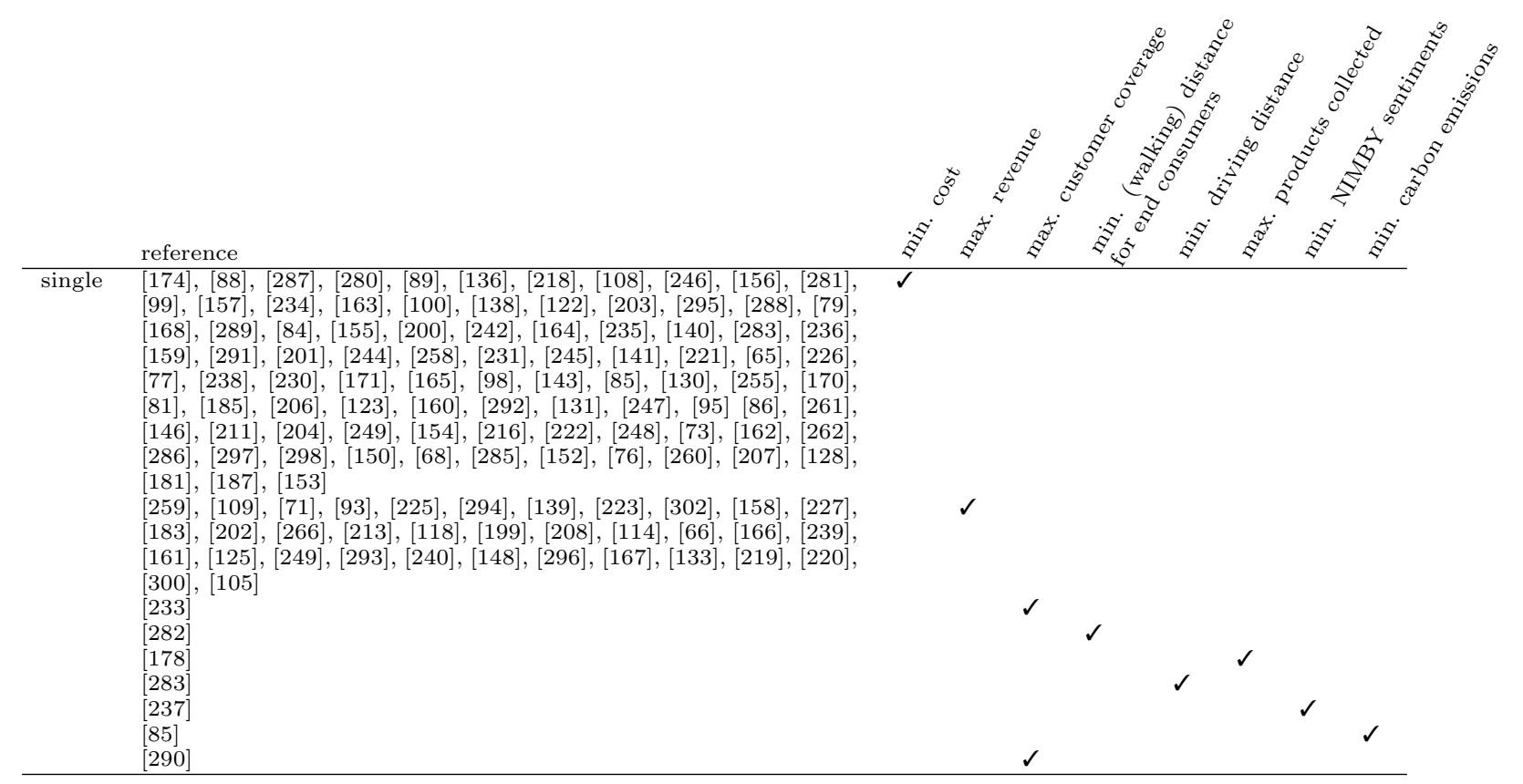


Table A.3: Overview of multi-objective models. A no preference methods does not use information from a Decision Maker (DM), and a single optimal solution is given. In a priori methods, a DM has to give some preferences before the model is solved. An a posteriori method presents the entire range of efficient solutions. GP = Goal Programming, EA = Evolutionary Algorithm; WT = Weighted Tchebycheff method.

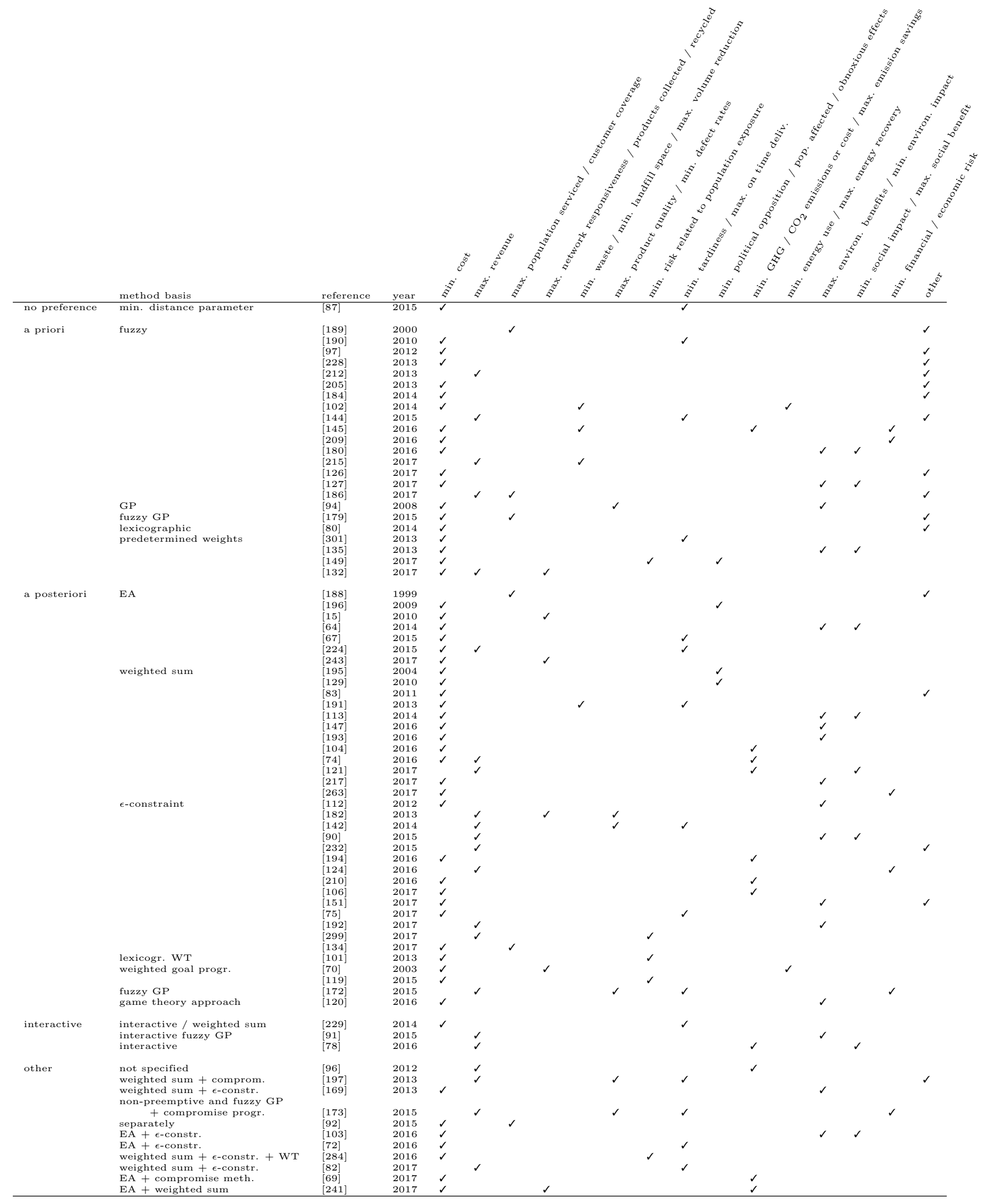


Table A.4: Applications of models. The third column indicates the WM or RL focus of the paper. Column four represents the studied waste type in each paper. The geographic location is given in column five. The last column indicates whether a fictional illustrative example is included. Some papers present both a case study and a fictional example. Often, it is the case that models are generic, even if they are applied to a specific waste stream. MSW = Municipal Solid Waste, ELV = End-of-Life Vehicle, LPG = Liquefied Natural Gas, $\mathrm{WEEE}=$ Waste of Electrical and Electronic Equipment, C\&D = Construction and Demolition waste.

\begin{tabular}{|c|c|c|c|c|}
\hline article & year & context & waste type & application description \\
\hline Chang and Wang $[174]$ & 1995 & WM & MSW & site selection in Kaohsiung City, Taiwan \\
\hline Barros et al. [88] & 1998 & RL & sand & location model for sand recycling in The Netherlands \\
\hline $\begin{array}{l}\text { Antunes }[287] \\
\text { Ant }\end{array}$ & 1999 & WM & MSW & site selection in Centro Region, Portugal \\
\hline Chang and Wei [188] & 1999 & WM & Recyclables & $\begin{array}{l}\text { recycling drop-off stations and collection in Kaohsiung City, Taiwan }\end{array}$ \\
\hline Krikke et al. [280] & 1999 & $\mathrm{RL}$ & copiers & copier remanufacuring in The Netherlands and Czech Republic \\
\hline Chang and Wei [189] & 2000 & WM & MSW & site selection in Kaohsiung City, Taiwan \\
\hline Krikke et al. $[70]$ & 2003 & RL & refrigerators & closed-loop supply chain for refridgerators in Europe \\
\hline Schultmann et al. [89] & 2003 & RL & batteries & battery recycling in Germany \\
\hline Beamon and Fernandes [136] & 2004 & RL & generic & $\begin{array}{l}\text { illustrative example } \\
\text { illitily }\end{array}$ \\
\hline le Blanc et al. [259] & 2004 & $\mathrm{RL}$ & LPG tanks & recycling system for LB tanks in The Netherlands \\
\hline Rakas et al. [195] & 2004 & WM & hazardous waste & locating undesirable facilities in Prince George's County, Maryland US \\
\hline $\begin{array}{l}\text { Hong et al. }[218] \\
\text { Hong }\end{array}$ & 2006 & RL & WEEE & planning e-scrap reverse production system in State of Georgia, US \\
\hline Gomes Salema et al. [108] & 2007 & RL & office products & design of reverse logistic network for office products in Spain and Portugal \\
\hline Lieckens and Vandaele $[109]$ & 2007 & RL & generic & 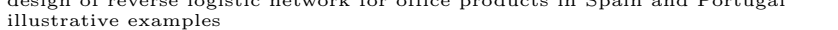 \\
\hline Sahyouni and Savaskan $[246]$ & 2007 & RL & generic & facility location study on cities in US and Europe \\
\hline de Figueiredo and Mayerle [156] & 2008 & $\mathrm{RL} / \mathrm{WM}$ & tires & design of tire recycling network in Paraná \& Santa Catarina Region, Brazil \\
\hline Mansour and Zarei $[281]$ & 2008 & $\mathrm{RL}$ & ELV & illustrative examples on ELV recovery \\
\hline 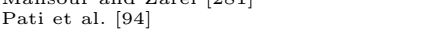 & 2008 & $\mathrm{RL} / \mathrm{WM}$ & paper & 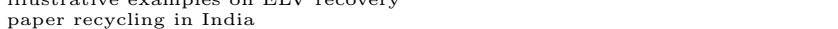 \\
\hline Srivastava $[71]$ & 2008 & RL & $\begin{array}{l}\text { paper } \\
\text { generic }\end{array}$ & modular product recovery in India \\
\hline Gomes Salema et al. [93] & 2009 & RL & generic & strategic and tactical ND in Spain and Portugal \\
\hline Lee and Chan [233] & 2009 & RL & printers/copiers & $\begin{array}{l}\text { example on printer/copier recovery } \\
\text { exal }\end{array}$ \\
\hline Medaglia et al. [196] & 2009 & WM & hospital waste & disposal of hospital waste in Boyac Region, Colombia \\
\hline Mitropoulos et al. [99] & 2009 & WM & MSW & location analysis for MSW treatment and disposal in Achaia Region, Greece \\
\hline Fonseca et al. [129] & 2010 & $\mathrm{RL}$ & MSW + recyclables & location model for MSW and recyclable management in Cordoba Region, Spain \\
\hline Gomes Salema et al. [157] & 2010 & RL & $\begin{array}{l}\text { glass } \\
\text { glatecyciduies }\end{array}$ & design and planning of glass recycling in Portugal + illustrative examples \\
\hline $\begin{array}{l}\text { Kao et al. }[282] \\
\text { Kal. }\end{array}$ & 2010 & $\mathrm{WM}$ & recyclables & $\begin{array}{l}\text { location-allocation model in Hsinchu City, Taiwan } \\
\text { lotion }\end{array}$ \\
\hline Kara and Onut [225] & 2010 & RL & paper & paper recycling reverse logistic network design in Istanbul City, Turkey \\
\hline Pishvaee et al. [15] & 2010 & RL & generic & four test instances \\
\hline Pishvaee and Torabi [190] & 2010 & RL & generic & several numerical experiments \\
\hline $\begin{array}{l}\text { Wang and Hsu }[234] \\
\text { Wang }\end{array}$ & 2010 & RL & $\begin{array}{l}\text { generic } \\
\text { generic }\end{array}$ & $\begin{array}{l}\text { severar numerical experiments } \\
\text { illustrative examples }\end{array}$ \\
\hline Zarei et al. [163] & 2010 & RL & ELV & illustrative examples \\
\hline Dai et al. $[100]$ & 2011 & $\mathrm{WM}$ & MSW & MSW management in Beijing City, China \\
\hline Gomes et al. [138] & 2011 & WM & WEEE & WEEE recycling network in Portugal \\
\hline Mar-Ortiz et al. [122] & 2011 & RL & WEEE & WEEE recycling ND in Galicia Region, Spain \\
\hline $\begin{array}{l}\text { Pishvaee et al. }[203] \\
\text { Pis }\end{array}$ & 2011 & RL & $\begin{array}{l}\text { Weneric } \\
\text { gener }\end{array}$ & $\begin{array}{l}\text { four test problems } \\
\text { for }\end{array}$ \\
\hline Tuzkaya et al. [83] & 2011 & RL & white goods & $\begin{array}{l}\text { strategic ND application for white goods in Turkey } \\
\text { sotic }\end{array}$ \\
\hline Vidovic et al. [178] & 2011 & $\mathrm{RL}$ & ELV & positioning ELV collection points in Belgrade City, Serbia \\
\hline Abdallah et al. [295] & 2012 & $\mathrm{RL}$ & generic & illustrative examples \\
\hline Amin and Zhang [294] & 2012 & RL & computers & $\begin{array}{l}\text { illustrative examples } \\
\text { illatis }\end{array}$ \\
\hline Assavapokee and Wongthatsanekorn [139] & 2012 & RL & WEEE & reverse production infrastructure design in State of Texas, US \\
\hline $\begin{array}{l}\text { Chabane et al. [96] } \\
\text { Chaband }\end{array}$ & 2012 & RL & aluminium & $\begin{array}{l}\text { illustrative examples } \\
\text { illastructure design in blate or lexas, us }\end{array}$ \\
\hline Chatzouridis and Komilis $[288]$ & 2012 & WM & MSW & locating MSW transfer stations in East. Macedonia \& Thrace Region, Greece \\
\hline $\begin{array}{l}\text { Dat et al. [79] } \\
\text { Dat }\end{array}$ & 2012 & $\mathrm{RL}$ & WEEE & $\begin{array}{l}\text { illustrative examples } \\
\text { illation }\end{array}$ \\
\hline Hasani et al. [168] & 2012 & RL & food, high-tech electro & illustrative examples \\
\hline Kannan et al. [289] & 2012 & RL & plastic & $\begin{array}{l}\text { reverse logistics design for plastic in India } \\
\text { reveric }\end{array}$ \\
\hline Lee and Lee $[84]$ & 2012 & RL & bottles & forward and reverse logistics for bottles in Busan City, South Korea \\
\hline Lieckens and Vandaele $[223]$ & 2012 & RL & $\begin{array}{l}\text { botties } \\
\text { printers }\end{array}$ & $\begin{array}{l}\text { forward and reverse } 10 \text { gistics for bottes in Busan City, South Korea } \\
\text { example for printer recovery in US }\end{array}$ \\
\hline $\mathrm{zkr}$ and Baslgl [302] & 2012 & RL & generic & illustrative examples \\
\hline Pishvaee and Razmi [112] & 2012 & RL & medical waste & SC ND for used needles in Iran \\
\hline Vahdani et al. [155] & 2012 & RL & steel scrap & illustrative examples \\
\hline Vahdani et al. [97] & 2012 & RL & steel scrap & illustrative examples \\
\hline $\mathrm{Xu}$ and Wei $[200]$ & 2012 & $\mathrm{WM}$ & C\&D waste & location-allocation of $C \& D$ waste in China \\
\hline Zeballos et al. [158] & 2012 & RL & $\begin{array}{l}\text { glass } \\
\text { glaste }\end{array}$ & $\begin{array}{l}\text { glass collection in Portugal } \\
\text { gaste } 11 \text { Connd }\end{array}$ \\
\hline Zhou et al. $[242]$ & 2012 & RL & generic & $\begin{array}{l}\text { illustrative examples } \\
\text { illugat }\end{array}$ \\
\hline Amin and Zhang [197] & 2013 & RL & computers & illustrative examples \\
\hline Amin and Zhang [169] & 2013 & RL & copiers & illustrative examples \\
\hline Cardoso et al. [227] & 2013 & RL & generic & design and planning of $\mathrm{SC}$ in Europe \\
\hline De Rosa et al. [164] & 2013 & RL & generic & $\begin{array}{l}\text { illustrative examples } \\
\text { ill }\end{array}$ \\
\hline Diabat et al. [235] & 2013 & $\mathrm{RL}$ & computers & illustrative examples \\
\hline Eskandarpour et al. [191] & 2013 & RL & WEEE & post-sales ND for electronic waste repair in Iran \\
\hline Fahimnia et al. [140] & 2013 & RL & textile & textile recovery and impact of carbon pricing in Australia \\
\hline Galan et al. [283] & 2013 & $\mathrm{WM}$ & C\&D waste & facility location in Cantabria Region, Spain \\
\hline Golebiewski et al. [236] & 2013 & RL & ELV & location of vehicle recyling facilities in Mazovia Region, Poland \\
\hline Lee et al. $[301]$ a. $[200]$ & 2013 & RL & $\begin{array}{l}\text { LLV } \\
\text { generic }\end{array}$ & $\begin{array}{l}\text { illustrative examples } \\
\text { illing }\end{array}$ \\
\hline zceylan and Paksoy [228] & 2013 & RL & 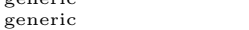 & illustrative examples \\
\hline zceylan and Paksoy [159] & 2013 & $\mathrm{RL}$ & generic & illustrative examples \\
\hline zceylan and Paksoy [291] & 2013 & RL & generic & illustrative examples \\
\hline $\mathrm{zkr}$ and Baslgl [212] & 2013 & $\mathrm{RL}$ & 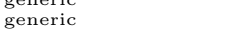 & illustrative examples \\
\hline $\begin{array}{l}\text { Phuc et al. }[201] \\
\text { Phr }\end{array}$ & 2013 & RL & $\begin{array}{l}\text { Weneric } \\
\text { WEEE }\end{array}$ & $\begin{array}{l}\text { 1IUStratve exampies } \\
\text { illustrative examples }\end{array}$ \\
\hline Ramezani et al. [182] & 2013 & RL & generic & illustrative examples \\
\hline Ramezani et al. [183] & 2013 & RL & generic & $\begin{array}{l}\text { illustrative examples } \\
\text { illustive }\end{array}$ \\
\hline Samanlioglu [101] & 2013 & WM & hazardous waste & location-routing of industrial hazardous waste in Marmara Region, Turkey \\
\hline Shokohyar and Mansour [135] & 2013 & RL & WEEE & WEEE recycling in Iran \\
\hline $\begin{array}{l}\text { Song et al. }[237] \\
\text { Song }\end{array}$ & 2013 & WM & 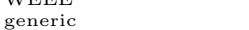 & $\begin{array}{l}\text { illustrative examples } \\
\text { illon }\end{array}$ \\
\hline Subramanian et al. [244] & 2013 & RL & WEEE & closed loop ND in India, illustrative examples \\
\hline $\begin{array}{l}\text { Subramanian et al. }[244] \\
\text { Vahdani et al. [205] }\end{array}$ & 2013 & $\begin{array}{l}\text { RL } \\
\text { RL }\end{array}$ & steel scrap & $\begin{array}{l}\text { illustrative examples } \\
\text { illa, illustrative examples }\end{array}$ \\
\hline Yao et al. $[258]$ & 2013 & WM & WEEE & design and optimization of WEEE collection in Shanghai City, China \\
\hline Alumur and Tari $[80]$ & 2014 & RL & WEEE & collection center location in Ankara City, Turkey \\
\hline Berglund and Kwon [231] & 2014 & WM & $\begin{array}{l}\text { hazardous waste } \\
\text { have }\end{array}$ & facility location in Albany Aera, US + Joaquin County CA, US \\
\hline $\begin{array}{l}\text { Chen et al. }[245] \\
\text { Chon }[231]\end{array}$ & 2014 & WM & $\begin{array}{l}\text { nazarcous waste } \\
\text { plastics }\end{array}$ & waste plastic recycling in Tokyo Region, Japan \\
\hline Demirel et al. $[184]$ & 2014 & RL & generic & $\begin{array}{l}\text { illustrative examples } \\
\text { ill }\end{array}$ \\
\hline Devika et al. [64] & 2014 & RL & glass & glass recovery in Iran \\
\hline Faccio et al. [141] & 2014 & RL & electric motors & reprocessing of electric motors in Northern Italy \\
\hline Hatefi and Jolai $[221]$ & 2014 & RL & generic & illustrative examples \\
\hline
\end{tabular}


continued from previous page

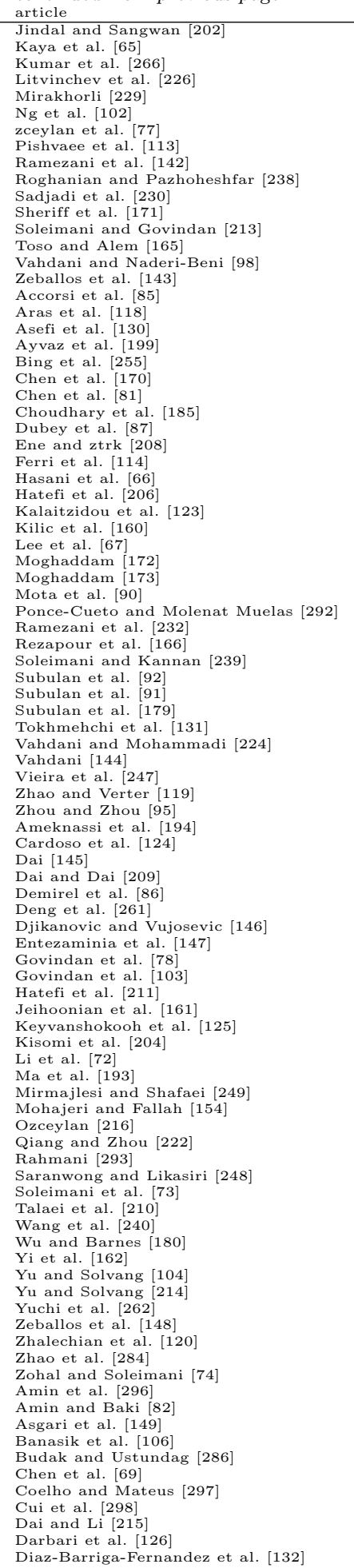

\begin{tabular}{|c|c|c|}
\hline year & context & waste type \\
\hline 2014 & RL & generic \\
\hline 2014 & $\mathrm{RL}$ & generic \\
\hline 2014 & $\mathrm{RL}$ & generic \\
\hline 2014 & $\mathrm{RL}$ & generic \\
\hline 2014 & $\mathrm{RL}$ & bread \\
\hline 2014 & WM & MSW \\
\hline 2014 & $\mathrm{RL}$ & WEEE \\
\hline 2014 & $\mathrm{RL}$ & medical waste \\
\hline 2014 & $\mathrm{RL}$ & generic \\
\hline 2014 & $\mathrm{RL}$ & generic \\
\hline 2014 & $\mathrm{RL}$ & generic \\
\hline 2014 & $\mathrm{RL}$ & plastic bottles \\
\hline 2014 & RL & generic \\
\hline 2014 & WM & recyclables \\
\hline 2014 & $\mathrm{RL}$ & steel scrap \\
\hline 2014 & RL & generic \\
\hline 2015 & RL & furniture \\
\hline 2015 & $\mathrm{RL}$ & WEEE \\
\hline 2015 & WM & MSW \\
\hline 2015 & $\mathrm{RL}$ & WEEE \\
\hline 2015 & RL & plastic \\
\hline 2015 & $\mathrm{RL}$ & toner cartridges \\
\hline 2015 & $\mathrm{RL}$ & WEEE \\
\hline 2015 & $\mathrm{RL}$ & generic \\
\hline 2015 & $\mathrm{RL}$ & air conditioners \\
\hline 2015 & $\mathrm{RL}$ & ELV \\
\hline 2015 & $\mathrm{RL} / \mathrm{WM}$ & MSW \\
\hline 2015 & RL & medical devices \\
\hline 2015 & $\mathrm{RL}$ & generic \\
\hline 2015 & $\mathrm{RL}$ & generic \\
\hline 2015 & $\mathrm{RL}$ & WEEE \\
\hline 2015 & $\mathrm{RL}$ & bottles \\
\hline 2015 & $\mathrm{RL}$ & generic \\
\hline 2015 & $\mathrm{RL}$ & generic \\
\hline 2015 & $\mathrm{RL}$ & batteries \\
\hline 2015 & $\mathrm{RL}$ & fridges \\
\hline 2015 & $\mathrm{RL}$ & generic \\
\hline 2015 & $\mathrm{RL}$ & automotive parts \\
\hline 2015 & $\mathrm{RL}$ & hospital furniture \\
\hline 2015 & $\mathrm{RL}$ & lead/acid batteries \\
\hline 2015 & $\mathrm{RL}$ & tires \\
\hline 2015 & $\mathrm{RL}$ & lead/acid batteries \\
\hline 2015 & $\mathrm{RL}$ & generic \\
\hline 2015 & RL & generic \\
\hline 2015 & $\mathrm{RL}$ & steel scrap \\
\hline 2015 & RL & generic \\
\hline 2015 & WM & used oil \\
\hline 2015 & $\mathrm{RL}$ & paper \\
\hline 2016 & $\mathrm{RL}$ & generic \\
\hline 2016 & $\mathrm{RL}$ & generic \\
\hline 2016 & $\mathrm{RL}$ & generic \\
\hline 2016 & $\mathrm{RL}$ & generic \\
\hline 2016 & $\mathrm{RL}$ & ELV \\
\hline 2016 & $\mathrm{RL}$ & generic \\
\hline 2016 & RL & electronics \\
\hline 2016 & $\mathrm{RL}$ & wood and paper \\
\hline 2016 & $\mathrm{RL}$ & geysers \\
\hline 2016 & $\mathrm{RL}$ & syringes \\
\hline 2016 & $\mathrm{RL}$ & generic \\
\hline 2016 & $\mathrm{RL}$ & durable products \\
\hline 2016 & $\mathrm{RL}$ & generic \\
\hline 2016 & $\mathrm{RL}$ & generic \\
\hline 2016 & $\mathrm{RL}$ & electronics \\
\hline 2016 & $\mathrm{RL}$ & generic \\
\hline 2016 & $\mathrm{RL}$ & short lifetime products \\
\hline 2016 & $\mathrm{RL}$ & notebooks \\
\hline 2016 & $\mathrm{RL}$ & camera \\
\hline 2016 & $\mathrm{RL}$ & generic \\
\hline 2016 & $\mathrm{RL}$ & generic \\
\hline 2016 & $\mathrm{RL}$ & farm products/waste \\
\hline 2016 & $\mathrm{RL}$ & $\begin{array}{l}\text { plastic bottles } \\
\text { plase }\end{array}$ \\
\hline 2016 & $\mathrm{RL}$ & copiers \\
\hline 2016 & $\mathrm{RL}$ & generic \\
\hline 2016 & $\mathrm{RL}$ & WEEE \\
\hline 2016 & $\mathrm{RL}$ & construction machinery \\
\hline 2016 & $\mathrm{RL}$ & general \\
\hline 2016 & $\mathrm{RL}$ & WEEE \\
\hline 2016 & $\mathrm{RL}$ & generic \\
\hline 2016 & $\mathrm{RL}$ & generic \\
\hline 2016 & RL & LCD and LED TVs \\
\hline 2016 & WM & hazardous waste \\
\hline 2016 & $\mathrm{RL}$ & gold \\
\hline 2017 & $\mathrm{RL}$ & tires \\
\hline 2017 & RL & generic \\
\hline 2017 & WM & obnoxious waste \\
\hline 2017 & $\mathrm{RL}$ & organic substrate/compost \\
\hline 2017 & $\mathrm{RL}$ & medical waste \\
\hline 2017 & RL & photovoltaic panels \\
\hline 2017 & $\mathrm{RL}$ & generic \\
\hline 2017 & $\mathrm{RL}$ & generic \\
\hline 2017 & RL & generic \\
\hline 2017 & RL & electronics \\
\hline 2017 & WM & MSW, recyclables \\
\hline
\end{tabular}

application description illustrative examples

illustrative examples

closed loop ND for bread industry in Iran

waste-to-energy network synthesis in Selangor Region, Malaysia

illustrative examples

medical needle and syringe supply chain in Iran

illustrative examples

illustrative examples

location routing in India, illustrative examples

illustrative examples

location for sorting recyclables in Sorocaba Region, Brazil

illustrative examples

illustrative examples

setwork in Italy

locating recycling facility for electronic waste in Turkey

location-routing with transfer stations in New South Wales Region, Australia

global SC design under emission trading scheme in The Netherlands - China

location-allocation and recycling decisions in Hong Kong

supply chain design for refrigerators in Germany

ustrative example

network design in Uttar Pradesh Region, India

network modelling examples and case study

ND for medical devices in Teheran City, Iran

illustrative examples

CLSC design case study for company in Europe

RL system design for WEEE in Turkey

reuse of bottles in Busan City, South Korea

illustrative examples

design of battery recycling SC in Portugal

reuse network for fridges in Spain

illustrative examples

realistic example for automotive part remanufacturing in Middle-Eas

ND for lead/acid battery recycling in Turkey

design of CLSC for tires in Aegean Region, Turkey

illustrative examples

illustrative examples

illustrative examples

location-routing for used oil in Chongquing Region, China

ND for office paper recycling in Xueyuang Road Aera, Beijing City, China case study of microwave oven remanufacturing in North America and Europe CLSC ND study in Europe

illustrative example

reverse logistics for ELV in Ankara City, Turkey

illustrative example

logistic model for electronics in Serbia and Europe

production and recycling planning for wood and paper industry in Iran

example on geyser recovery in India

reverse ND for syringe industry in Iran

illustrative example

illustrative example

illustrative example

illustrative example

illustrative example

illustrative example

ND for notebook remanufacturing in Iran

example on WEEE remanufacturing

examples on facility location

product distribution of farm waste in Northern Thailand

bottle recovery in India, illustrative examples

illustrative example

illustrative example

WEEE recovery ND in China
ND for end-of-life construction machinery in China

illustrative example

illustrative example

illustrative example

illustrative example

TV remanufacturing in Iran, illustrative example

ND for hazardous WM in Sichuan Province, China + illustrative example

CLSC ND for gold industry in Ira

tire CLSC network in Ontario Region, Canada

western Ontario, Canada

location-routing for hazardous materials in Singapore

example on industrial mushroon $\mathrm{SC}$

collection and disposal for medical waste in Turkey

illustrative example

remanufacturing example in Chin

illustrative example

configuration of SC for electronics in New Delhi City, India

strategic planning for MSW management in Mexico 
continued from previous page

Entezaminia et al. [150]

Fattahi and Govindan [167]

Fu et al. [243]

Hamidieh et al. [75]

Harijani et al. [121]

Harijani et al. [133]
Jeihoonian et al. [219]

Jindal and Sangwan [192]

Kang et al. [68]

Keivanpour et al. [127]

Keshavarz Ghorabaee et al. [217]

$\mathrm{Li}$ et al. [285]

Mohammed et al. [152]

Paydar et al. [299]

Pedram et al. $[220]$

Phuc et al. [76]

Safaei et al. [300]

Sampat et al. [134]

Sheriff et al. [260]

Soleimani et al. [186]

[207]

Uster and Hwang [128]

Wang et al. [181]

$\mathrm{Xu}$ et al. [187]

Xu et al. [153]
Xue et al. [290]

Xue et al. [290]

Yu and Solvang [105]
Zhao and Ke [263]

\begin{tabular}{llll} 
year & context & waste type & application description \\
2017 & RL & wood and paper & production and recycling planning for wood and paper industry in Iran \\
2017 & RL & generic & illustrative example \\
2017 & RL & plastic & redesign of reverse SC for plastic in Cuba \\
2017 & RL & C\&D & illustrative example \\
2017 & RL & notebooks & SC ND for notebook repair and refurbish in Iran \\
2017 & WM & MSW, recyclables & model for recycling of MSW in Teheran, Iran \\
2017 & WM & MSW, recyclables & model for recycling of MSW in Teheran, Iran \\
2017 & RL & durable products & illustrative example \\
2017 & RL & generic & illustrative example \\
2017 & RL & bottles & case study for beer company in a developing country \\
2017 & RL & EoL aircraft & illustrative example \\
2017 & RL & home appliances & illustrative example \\
2017 & WM & MSW & integrated MSW management in Regina City, Canada \\
2017 & RL & automotive parts & illustrative example \\
2017 & RL & engine oil & ND for oil recycling in Iran \\
2017 & RL & tires & tire remanufacturing in Iran \\
2017 & RL & ELV & illustrative example \\
2017 & RL & cardboard & paper recycling network in Amol City, Iran \\
2017 & WM & organic waste & livestock organic WM in Wisconsin State, USA \\
2017 & WM & MSW, recyclables & optimization model for plastics recycling in India \\
2017 & RL & generic & CL ND in 95 cities in Hunan Province, China + illustrative examples \\
2017 & RL & generic & illustrative example \\
2017 & RL & WEEE & ND for WEEE recycling in Turkey + illustrative example \\
2017 & RL & generic & numerical remanufacturing study based on 263 largest cities in US \\
2017 & RL & generic & illustrative example \\
2017 & RL & e-waste & global SC design for recycling in Greece and China \\
2017 & RL & plastic products & illustrative example \\
2017 & WM & mixed & location of urban mines in China \\
2017 & RL & general & illustrative example \\
2017 & WM & explosive waste & location-routing for explosive waste from bauxite mining in Nanchuan City, China \\
\hline
\end{tabular}


Table A.5: Overview of papers handling uncertainty. The rows indicate the approach to deal with uncertainty. The parameters subject to uncertainty are listed in the columns.

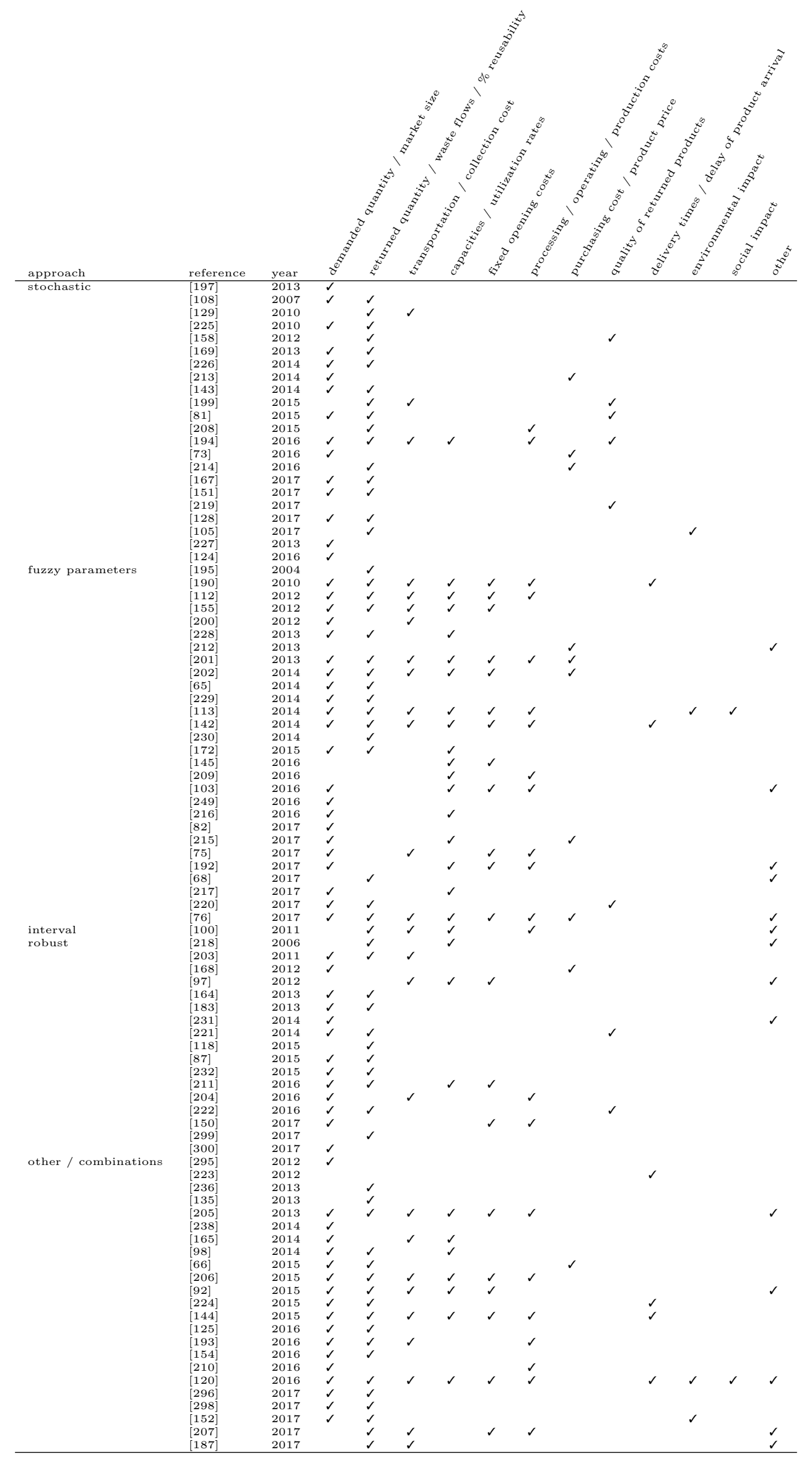


Table A.6: Solution methods of reviewed models. Columns three, four and five indicate whether the model incorporates uncertainty, multiple objectives and non-linearities. When a model is linearized before solving, this is indicated by "(lin)" in column five. Column six indicates if a model is solved exactly (exact), heuristically (heur.), by a combination of both (exact + heur., e.g. global heuristic for first stage location decisions combined with an exact procedure in for allocation in a second stage) or in two separate ways (exact / heur., often to compare exact to heuristic solutions). The last column provides information about the applied heuristic, if it is specified. unc. = model incorporates uncertainty; $\mathrm{MO}=$ multi objective model; $\mathrm{NL}=$ non-linear model; $\mathrm{GA}=$ Genetic Algorithm; PSO = Particle Swarm Optimization; AIS = Artificial Immune System; VNS = Variable Neighborhood Search; SA = Simulated Annealing; AC = Ant Colony; ICA = Imperialist Competitive Algorithm; (A)BD = (Accelerated) Benders Decomposition; MA = Memetic Algorithm, combining GA and local search; SAA = Sample Average Approximation; VI = Variational Inequality; ABC = Artificial Bee Colony.

\begin{tabular}{|c|c|c|c|c|c|c|}
\hline article & year & unc. & $\mathrm{MO}$ & NL & exact / heuristic & solver / solution technique \\
\hline Chang and Wang [174] & 1995 & & & & exact & LINDO \\
\hline Barros et al. [88] & 1998 & & & & heur. & GAMS \\
\hline Antunes $[287]$ & 1999 & & & & exact & XPRESS-MP \\
\hline Chang and Wei [188] & 1999 & & $\checkmark$ & $\checkmark$ & heur. & GA \\
\hline Krikke et al. $[280]$ & 1999 & & & & exact & LINDO \\
\hline Chang and Wei [189] & 2000 & & $s$ & 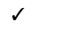 & heur. & GA \\
\hline Krikke et al. [70] & 2003 & & 8 & & exact & CPLEX \\
\hline Schultmann et al. [89] & 2003 & & & & exact & GAMS \\
\hline Beamon and Fernandes [136] & 2004 & & & & unclear & 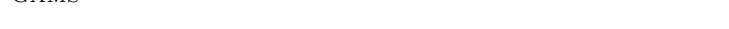 \\
\hline le Blanc et al. [259] & 2004 & & & & exact + heur. & AIMMS with CPLEX + nearest neighbor and local search techniques \\
\hline Rakas et al. [195] & 2004 & 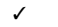 & $\checkmark$ & & exact & CPLEX \\
\hline Hong et al. $[218]$ & 2006 & 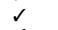 & & & exact + heur. & CPLEX + heuristic as described in [303] \\
\hline Gomes Salema et al. [108] & 2007 & $\mathrm{~s}$ & & & exact & GAMS + CPLEX \\
\hline Lieckens and Vandaele [109] & 2007 & & & $\checkmark$ & heur. & GA \\
\hline Sahyouni and Savaskan $[246]$ & 2007 & & & & exact / heur. & CPLEX / lagrangian relaxation \\
\hline de Figueiredo and Mayerle [156] & 2008 & & & $\checkmark$ & heur. & modified Teitz and Bart procedure coupled \\
\hline Mansour and Zarei [281] & 2008 & & & & heur. & $\begin{array}{l}\text { with Fibonacci and bisection search methods } \\
\text { multiple start search algorithm }\end{array}$ \\
\hline Pati et al. [94] & 2008 & & $\checkmark$ & & exact & LINDO \\
\hline Srivastava $[71]$ & 2008 & & & & exact & GAMS + CPLEX \\
\hline Gomes Salema et al. [93] & 2009 & & & & exact & GAMS + CPLEX \\
\hline Lee and Chan [233] & 2009 & & & 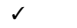 & heur. & $\mathrm{GA}$ \\
\hline Medaglia et al. [196] & 2009 & & $\checkmark$ & & exact + heur. & XPRESS-MP + GA \\
\hline Mitropoulos et al. [99] & 2009 & & & & exact & Premium solver + XPRESS \\
\hline Fonseca et al. [129] & 2010 & $\checkmark$ & & & exact & CPLEX \\
\hline Gomes Salema et al. [157] & 2010 & ( & & & exact & GAMS + CPLEX \\
\hline Kao et al. [282] & 2010 & & & & exact & CPLEX \\
\hline Kara and Onut [225] & 2010 & $\checkmark$ & & & exact & GAMS + CPLEX \\
\hline Pishvaee et al. [15] & 2010 & & $\checkmark$ & $\checkmark(\operatorname{lin})$ & exact / heur. & LINGO / GA \\
\hline Pishvaee and Torabi [190] & 2010 & $\checkmark$ & 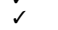 & (1111) & exact & LINGO \\
\hline Wang and Hsu [234] & 2010 & & & & exact / heur. & LINGO, CPLEX / GA \\
\hline Zarei et al. [163] & 2010 & & & & exact / heur. & LINGO / GA \\
\hline Dai et al. $[100]$ & 2011 & 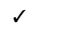 & & & unclear & \\
\hline Gomes et al. [138] & 2011 & & & & exact & GAMS + CPLEX \\
\hline Mar-Ortiz et al. [122] & 2011 & & & & exact $+/$ heur. & CPLEX + / savings-based heuristic \\
\hline Pishvaee et al. [203] & 2011 & $d$ & & & exact & CPLEX \\
\hline Tuzkaya et al. [83] & 2011 & & $\checkmark$ & $\checkmark$ & heur. & GA \\
\hline Vidovic et al. $[178]$ & 2011 & & & & exact & LPSolve IDE \\
\hline Abdallah et al. [295] & 2012 & 2 & & 2 & exact & GAMS \\
\hline Amin and Zhang [294] & 2012 & & & & exact & GAMS \\
\hline Assavapokee and Wongthatsanekorn [139] & 2012 & & & & exact & GAMS + CPLEX \\
\hline Chaabane et al. [96] & 2012 & & $\checkmark$ & & exact & LINGO \\
\hline Chatzouridis and Komilis [288] & 2012 & & & $\checkmark(\operatorname{lin})$ & exact & Excel + LINDO add-on \\
\hline Dat et al. [79] & 2012 & & & & exact & AMPL + CPLEX \\
\hline Hasani et al. [168] & 2012 & $s$ & & & exact & LINGO \\
\hline Kannan et al. [289] & 2012 & & & & exact & LINGO \\
\hline Lee and Lee $[84]$ & 2012 & & & $\checkmark$ & exact / heur. & LINGO / GA \\
\hline Lieckens and Vandaele [223] & 2012 & $\checkmark$ & & $s$ & heur. & GA \\
\hline $\mathrm{zkr}$ and Baslgl [302] & 2012 & & & & exact & GAMS \\
\hline Pishvaee and Razmi [112] & 2012 & 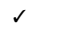 & $\checkmark$ & & exact & LINDO \\
\hline Vahdani et al. [155] & 2012 & $s$ & & $\checkmark$ & exact & GAMS \\
\hline Vahdani et al. [97] & 2012 & 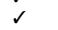 & $\checkmark$ & & exact & GAMS \\
\hline $\mathrm{Xu}$ and Wei $[200]$ & 2012 & $s$ & & & heur. & PSO-based heuristic \\
\hline Zeballos et al. [158] & 2012 & 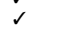 & & & exact & GAMS + CPLEX \\
\hline Zhou et al. [242] & 2012 & & & & heur. & PSO \\
\hline Amin and Zhang [197] & 2013 & $s$ & $s$ & $\checkmark$ & exact & GAMS \\
\hline Amin and Zhang [169] & 2013 & $s$ & 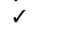 & & exact & CPLEX \\
\hline Cardoso et al. $[227]$ & 2013 & 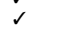 & & & exact & GAMS + CPLEX \\
\hline De Rosa et al. [164] & 2013 & $\checkmark$ & & & exact & IBM ILOG CPLEX Optimization Studio \\
\hline Diabat et al. [235] & 2013 & & & $\checkmark$ & heur. & GA / AIS \\
\hline Eskandarpour et al. [191] & 2013 & & $\checkmark$ & $\checkmark(\operatorname{lin})$ & exact / heur. & LINGO, Gurobi / VNS \\
\hline Fahimnia et al. [140] & 2013 & & & & exact & AMPL + CPLEX \\
\hline Galan et al. $[283]$ & 2013 & & & & exact & GAMS \\
\hline Golebiewski et al. [236] & 2013 & $d$ & & 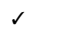 & heur. & GA \\
\hline Lee et al. [301] & 2013 & & & 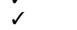 & exact & GAMS \\
\hline zceylan and Paksoy [159] & 2013 & & & & exact & GAMS + CPLEX \\
\hline zceylan and Paksoy [228] & 2013 & 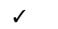 & $\checkmark$ & & exact & GAMS + CPLEX \\
\hline zceylan and Paksoy [291] & 2013 & & & $\checkmark$ & exact & GAMS + BARON \\
\hline $\mathrm{zkr}$ and Baslgl $[212]$ & 2013 & $d$ & $\checkmark$ & & exact & GAMS + BARON \\
\hline Phuc et al. [201] & 2013 & $s$ & & & exact & MATLAB \\
\hline Ramezani et al. [182] & 2013 & & $s$ & & unclear & \\
\hline Ramezani et al. [183] & 2013 & $s$ & & & exact & GAMS + CPLEX \\
\hline Samanlioglu [101] & 2013 & & $\checkmark$ & & exact & CPLEX \\
\hline Shokohyar and Mansour [135] & 2013 & $\checkmark$ & $\checkmark$ & & heur. & Simulation Based Optimization \\
\hline $\begin{array}{l}\text { Song et al. [237] } \\
\text { Song }\end{array}$ & 2013 & & & $\checkmark$ & exact / heur. & CPLEX / GA \\
\hline Subramanian et al. [244] & 2013 & & & & exact / heur. & CPLEX / Priority based SA \\
\hline Vahdani et al. [205] & 2013 & $\checkmark$ & $\checkmark$ & & exact & GAMS \\
\hline Yao et al. $[258]$ & 2013 & & & & exact $/+$ heur. & LINGO / AC algorithm \\
\hline Alumur and Tari [80] & 2014 & & $\checkmark$ & $\checkmark(\operatorname{lin})$ & exact & CPLEX \\
\hline
\end{tabular}


continued from previous page

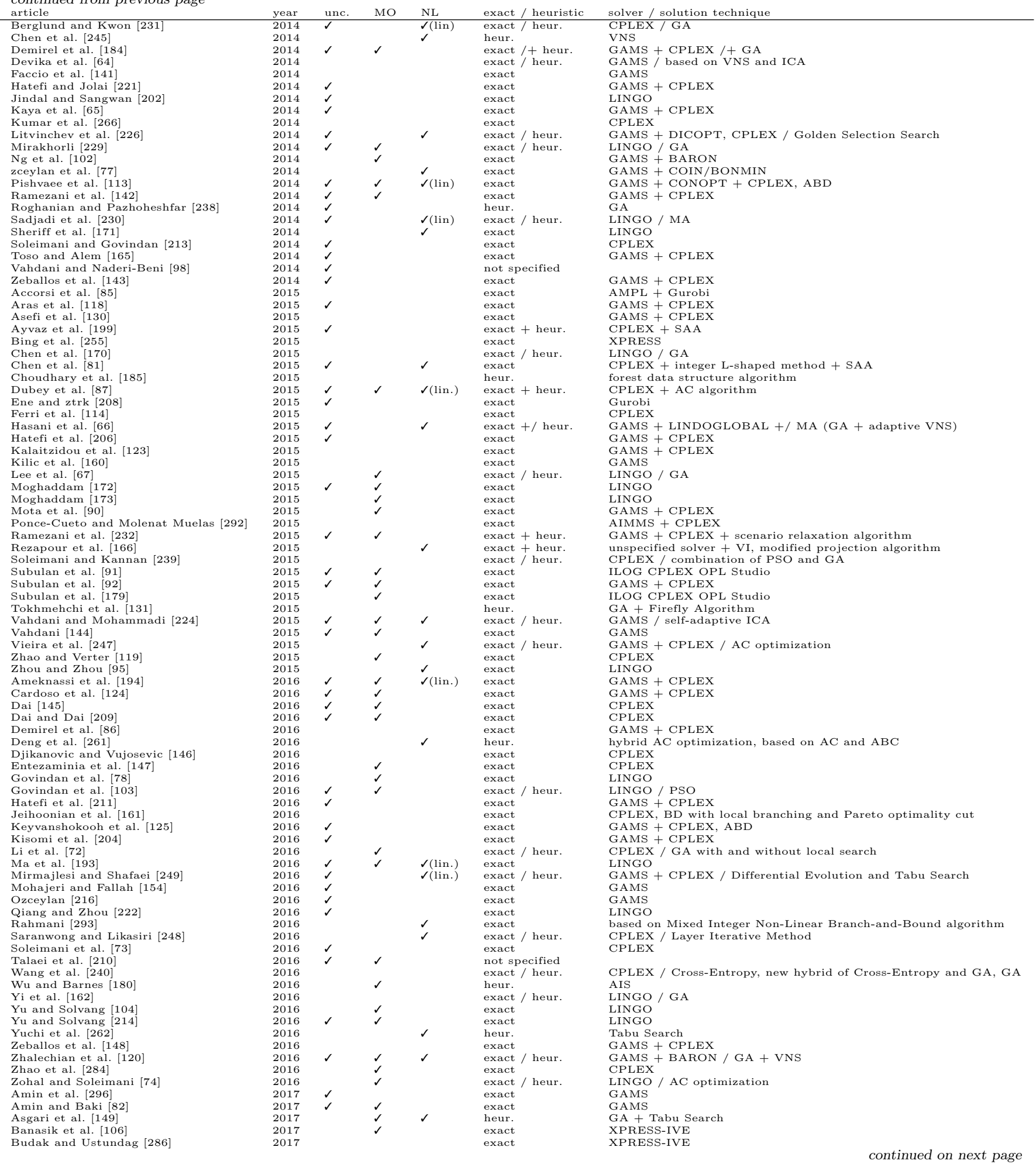




\begin{tabular}{|c|c|c|c|c|c|c|}
\hline article & year & unc. & MO & NL & exact / heuristic & solver / solution technique \\
\hline Chen et al. [69] & 2017 & & $\checkmark$ & & exact / heur. & CPLEX / PSO \\
\hline Coelho and Mateus [297] & 2017 & & & & exact / heur. & CPLEX, BD in AMPL \\
\hline Cui et al. [298] & 2017 & $\checkmark$ & & $\checkmark$ & heur. & ABC algorithm \\
\hline Dai and $\mathrm{Li}[215]$ & 2017 & 3 & $\checkmark$ & & exact & CPLEX \\
\hline Darbari et al. [126] & 2017 & & $\checkmark$ & & exact & LINGO \\
\hline Diaz-Barriga-Fernandez et al. [132] & 2017 & & $\checkmark$ & $\checkmark($ lin. $)$ & exact & GAMS + BARON \\
\hline Entezaminia et al. [150] & 2017 & 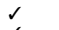 & & $\checkmark(\operatorname{lin})$. & exact & CPLEX \\
\hline Fattahi and Govindan [167] & 2017 & 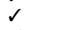 & & & exact / heur. & GAMS + CPLEX / simulation based SA \\
\hline Feito-Cespon et al. [151] & 2017 & $\checkmark$ & $\checkmark$ & $\checkmark$ & exact & MATLAB + SCIP \\
\hline Fu et al. [243] & 2017 & & 1 & & heuristic & PSO \\
\hline Hamidieh et al. [75] & 2017 & $\checkmark$ & $s$ & $\checkmark($ lin. $)$ & unclear & \\
\hline Harijani et al. [121] & 2017 & & $\mathrm{~s}$ & & exact & CPLEX \\
\hline Harijani et al. [133] & 2017 & & & & exact & CPLEX \\
\hline Jeihoonian et al. [219] & 2017 & & & & exact & CPLEX, based on L-shaped algorithm \\
\hline Jindal and Sangwan [192] & 2017 & 1 & $\checkmark$ & & exact & LINGO \\
\hline Kang et al. [68] & 2017 & 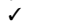 & & & heur. & PSO, AIS \\
\hline Keivanpour et al. [127] & 2017 & $\checkmark$ & $\checkmark$ & $\checkmark$ & heur. & $\mathrm{GA}$ \\
\hline $\mathrm{Li}$ et al. [285] & 2017 & & & $\checkmark$ & heur. & iterative algorithm \\
\hline Mohammed et al. [152] & 2017 & $\checkmark$ & & & exact & GAMS + CPLEX \\
\hline Paydar et al. [299] & 2017 & 2 & 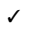 & & exact & LINGO \\
\hline Pedram et al. $[220]$ & 2017 & 3 & & & exact & GAMS + CPLEX \\
\hline Phuc et al. $[76]$ " & 2017 & 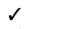 & & & unclear & \\
\hline Safaei et al. [300] & 2017 & 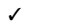 & & & exact & LINGO \\
\hline Sampat et al. [134] & 2017 & & $\checkmark$ & & exact & Gurobi \\
\hline Sheriff et al. $[260]$ & 2017 & & & 2 & exact & LINGO \\
\hline Shi et al. [241] & 2017 & & $\checkmark$ & & heur. & $\mathrm{GA}$ \\
\hline Soleimani et al. [186] & 2017 & & 1 & & exact / heur. & LINGO / GA \\
\hline Temur and Yanik [207] & 2017 & $\checkmark$ & & & exact / heur & GAMS + CPLEX / Cloud Based Design Optimization (CBDO) \\
\hline Uster and Hwang [128] & 2017 & $\checkmark$ & & & exact & CPLEX, enhanced BD \\
\hline Wang et al. [181] & 2017 & & & $\checkmark$ & heur. & Plant Growth Simulation Algorithm \\
\hline $\mathrm{Xu}$ et al. $[187]$ & 2017 & $\checkmark$ & & & exact & GAMS + CPLEX \\
\hline $\mathrm{Xu}$ et al. $[153]$ & 2017 & & & & exact & IBM ILOG CPLEX Optimization Studio \\
\hline Xue et al. $[290]$ & 2017 & & & & exact & GIS \\
\hline Yu and Solvang [105] & 2017 & $\checkmark$ & & & exact & LINGO \\
\hline Zhao and Ke [263] & 2017 & & $\checkmark$ & & exact & CPLEX \\
\hline
\end{tabular}




\section{References}

[1] L. Herbert, Centenary history of waste and waste managers in London and South East England, Chartered Institution of Wastes Management (2007).

[2] European Commission, Communication form the Commission to the European Parliament, the Council, the European Economic and Social Committee and the Committee of the Regions: Closing the loop - An EU action plan for the Circular Economy, 2015.

[3] Apple, Renew and Recycling, 2018. URL: https://www. apple.com/recycling/.

[4] UPS, Reverse Logistics :: UPS Supply Chain Solutions, 2018. URL: https://www .ups-scs .com/logistics/returns.html.

[5] H\&M, H\&M group | Recycle your clothes, 2018. URL: https://about.hm.com/en/sustainability/get-involved/ recycle-your-clothes.html.

[6] Dasani, Dasani Sustainability, 2018. URL: https://www . dasani.com/product-locator.html.

[7] Dell, Dell Recycling | Dell, 2018. URL: http://www .dell.com/ learn/us/en/uscorp1/dell-environment-recycling.

[8] A. Robinson, The Top 6 Trends in Logistics Impacting Shippers in 2017, 2017. URL: http://cerasis.com/2017/02/13/ trends-in-logistics/.

[9] O. Balch, The future of waste: five things to look for by 2025 , The Guardian (2015).

[10] K. d. Freytas-Tamura, Plastics Pile Up as China Refuses to Take the Wests Recycling, The New York Times (2018).

[11] D. S. Rogers, R. S. Tibben-Lembke, Going Backwards: Reverse Logistics Trends and Practices, Pittsburgh, PA, 1999.

[12] J. R. Stock, Development and implementation of reverse logistics programs, 1st edition ed., Council of Logistics Management, 1998

[13] United Nations Department for Economic and Social Information and Policy Analysis, Glossary of environment statistics, Studies in methods, United Nations, 1997.

[14] R. Kahhat, R. Navia, A reverse supply chain can enhance waste management programmes, Waste Management \& Research 31 (2013) 1081-1082.

[15] M. S. Pishvaee, R. Z. Farahani, W. Dullaert, A memetic algorithm for bi-objective integrated forward/reverse logistics network design, Computers \& Operations Research 37 (2010) 1100-1112.

[16] M. Thierry, M. Salomon, J. Van Nunen, L. Van Wassenhove, Strategic issues in product recovery management, California Management Review 37 (1995) 114.

[17] C. Carter, L. Ellram, Reverse logistics: a review of the litera- ture and framework for future investigation 19 (1998) 85-102.

[18] M. Fleischmann, J. M. Bloemhof-Ruwaard, R. Dekker, E. van der Laan, J. A. E. E. van Nunen, L. N. Van Wassenhove, Quantitative models for reverse logistics: A review, European Journal of Operational Research 103 (1997) 1-17.

[19] M. Fleischmann, H. R. Krikke, R. Dekker, S. D. P. Flapper, A characterisation of logistics networks for product recovery, Omega 28 (2000) 653-666.

[20] V. D. R. Guide, V. Jayaraman, R. Srivastava, Production planning and control for remanufacturing: a state-of-the-art survey, Robotics and Computer-Integrated Manufacturing 15 (1999) 221-230.

[21] C. S. ReVelle, H. A. Eiselt, Location analysis: A synthesis and survey - Invited review, European Journal of Operational Research 165 (2005) 1-19.

[22] H. Min, V. Jayaraman, R. Srivastava, Combined locationrouting problems: A synthesis and future research directions, European Journal of Operational Research 108 (1998) 1-15.

[23] G. Nagy, S. Salhi, Location-routing: Issues, models and methods, European Journal of Operational Research 177 (2007) 649-672.

[24] S. H. Owen, M. S. Daskin, Strategic facility location: A review, European journal of operational research 111 (1998) 423-447.

[25] L. V. Snyder, Facility location under uncertainty: a review, IIE Transactions 38 (2006) 547-564.

[26] M. Goetschalckx, C. J. Vidal, K. Dogan, Modeling and design of global logistics systems: A review of integrated strategic and tactical models and design algorithms, European journal of operational research 143 (2002) 1-18.

[27] M. J. Meixell, V. B. Gargeya, Global supply chain design: A literature review and critique, Transportation Research Part E: Logistics and Transportation Review 41 (2005) 531-550.

[28] Z. Shen, Integrated supply chain design models: a survey and future research directions, Journal of Industrial and Management Optimization 3 (2007) 1.

[29] A. Gungor, S. M. Gupta, Issues in environmentally conscious manufacturing and product recovery: a survey, Computers \& Industrial Engineering 36 (1999) 811-853.

[30] S. K. Srivastava, Green supply-chain management: A stateof-the-art literature review, International Journal of Management Reviews 9 (2007) 53-80.

[31] P. Sasikumar, G. Kannan, Issues in reverse supply chains, part II: reverse distribution issues an overview, International Journal of Sustainable Engineering 1 (2008) 234-249.

[32] P. Sasikumar, G. Kannan, Issues in reverse supply chains, part I: endoflife product recovery and inventory management 
an overview, International Journal of Sustainable Engineering 1 (2008) 154-172.

[33] P. Sasikumar, G. Kannan, Issues in reverse supply chain, part III: classification and simple analysis, International Journal of Sustainable Engineering 2 (2009) 2-27.

[34] S. Rubio, A. Chamorro, F. J. Miranda, Characteristics of the research on reverse logistics (1995-2005), International Journal of Production Research 46 (2008) 1099-1120.

[35] S. Pokharel, A. Mutha, Perspectives in reverse logistics: A review, Resources, Conservation and Recycling 53 (2009) 175182.

[36] M. A. Ilgin, S. M. Gupta, Environmentally conscious manufacturing and product recovery (ECMPRO): A review of the state of the art, Journal of Environmental Management 91 (2010) 563-591.

[37] R. Dekker, J. Bloemhof, I. Mallidis, Operations Research for green logistics An overview of aspects, issues, contributions and challenges, European Journal of Operational Research 219 (2012) 671-679.

[38] S. Seuring, A review of modeling approaches for sustainable supply chain management, Decision Support Systems 54 (2013) 1513-1520.

[39] H. Min, I. Kim, Green supply chain research: past, present, and future, Logistics Research 4 (2012) 39-47.

[40] C. Lin, K. L. Choy, G. T. S. Ho, S. H. Chung, H. Y. Lam Survey of Green Vehicle Routing Problem: Past and future trends, Expert Systems with Applications 41 (2014) 11181138.

[41] L. Chen, J. Olhager, O. Tang, Manufacturing facility location and sustainability: A literature review and research agenda, International Journal of Production Economics 149 (2014) 154-163.

[42] M. Eskandarpour, P. Dejax, J. Miemczyk, O. Peton, Sustainable supply chain network design: An optimization-oriented review, Omega-International Journal of Management Science 54 (2015) 11-32.

[43] N. Juul, M. Munster, H. Ravn, M. L. Soderman, Challenges when performing economic optimization of waste treatment: A review, Waste Management 33 (2013) 1918-1925.

[44] D. W. Steeneck, S. C. Sarin, Pricing and production planning for reverse supply chain: a review, International Journal of Production Research 51 (2013) 6972-6989.

[45] P. Chanintrakul, A. E. C. Mondragon, C. Lalwani, C. Y. Wong, Reverse logistics network design: a state-of-the-art literature review, International Journal of Business Performance and Supply Chain Modelling 1 (2009) 61.

[46] E. Akal, S. etinkaya, H. ster, Network design for reverse and closed-loop supply chains: An annotated bibliography of models and solution approaches, Networks 53 (2009) 231-248.

[47] M. Fleischmann, Reverse Logistics Network Structures and Design, SSRN Working Paper Series (2003).

[48] A. Jayant, P. Gupta, S. K. Garg, Perspectives in reverse supply chain management (R-SCM): A state of the art literature review, JJMIE 6 (2012).

[49] M. Aravendan, R. Panneerselvam, Literature Review on Network Design Problems in Closed Loop and Reverse Supply Chains, Intelligent Information Management 06 (2014) 104117.

[50] D. Stindt, R. Sahamie, Review of research on closed loop supply chain management in the process industry, Flexible Services and Manufacturing Journal 26 (2014) 268-293.

[51] M. T. Melo, S. Nickel, F. Saldanha-da Gama, Facility location and supply chain management - A review, European Journal of Operational Research 196 (2009) 401-412.

[52] D. Peidro, J. Mula, R. Poler, F.-C. Lario, Quantitative models for supply chain planning under uncertainty: a review, The International Journal of Advanced Manufacturing Technology 43 (2009) 400-420

[53] R. Z. Farahani, M. SteadieSeifi, N. Asgari, Multiple criteria facility location problems: A survey, Applied Mathematical Modelling 34 (2010) 1689-1709.

[54] W. Klibi, A. Martel, A. Guitouni, The design of robust valuecreating supply chain networks: A critical review, European Journal of Operational Research 203 (2010) 283-293.

[55] R. Z. Farahani, S. Rezapour, T. Drezner, S. Fallah, Competitive supply chain network design: An overview of classifications, models, solution techniques and applications, Omega 45 (2014) 92-118.

[56] G. Ghiani, D. Lagan, E. Manni, R. Musmanno, D. Vigo, Operations research in solid waste management: A survey of strategic and tactical issues, Computers \& Operations Research 44 (2014) 22-32.

[57] S. Agrawal, R. K. Singh, Q. Murtaza, A literature review and perspectives in reverse logistics, Resources, Conservation and Recycling 97 (2015) 76-92.

[58] K. Govindan, H. Soleimani, D. Kannan, Reverse logistics and closed-loop supply chain: A comprehensive review to explore the future, European Journal of Operational Research 240 (2015) 603-626.

[59] K. Govindan, M. Fattahi, E. Keyvanshokooh, Supply chain network design under uncertainty: A comprehensive review and future research directions, European Journal of Operational Research 263 (2017) 108-141.

[60] X. Bing, J. M. Bloemhof, T. R. P. Ramos, A. P. Barbosa- 
Povoa, C. Y. Wong, J. G. A. J. van der Vorst, Research challenges in municipal solid waste logistics management, Waste Management 48 (2016) 584-592.

[61] K. Govindan, H. Soleimani, A review of reverse logistics and closed-loop supply chains: a Journal of Cleaner Production focus, Journal of Cleaner Production 142 (2017) 371-384.

[62] e. Pine, M. Ferguson, B. Toktay, Extracting Maximum Value from Consumer Returns: Allocating Between Remarketing and Refurbishing for Warranty Claims, Manufacturing \& Service Operations Management 18 (2016) 475-492.

[63] Deloitte, Used smartphones: the $\$ 17$ billion market you may never have heard of, 2016.

[64] K. Devika, A. Jafarian, V. Nourbakhsh, Designing a sustainable closed-loop supply chain network based on triple bottom line approach: A comparison of metaheuristics hybridization techniques, European Journal of Operational Research 235 (2014) 594-615.

[65] O. Kaya, F. Bagci, M. Turkay, Planning of capacity, production and inventory decisions in a generic reverse supply chain under uncertain demand and returns, International Journal of Production Research 52 (2014) 270-282.

[66] A. Hasani, S. H. Zegordi, E. Nikbakhsh, Robust closed-loop global supply chain network design under uncertainty: the case of the medical device industry, International Journal of Production Research 53 (2015) 1596-1624.

[67] J.-E. Lee, K.-Y. Chung, K.-D. Lee, M. Gen, A multi-objective hybrid genetic algorithm to minimize the total cost and delivery tardiness in a reverse logistics, Multimedia Tools and Applications 74 (2015) 9067-9085.

[68] K. Kang, X. Wang, Y. Ma, A Collection-Distribution Center Location and Allocation Optimization Model in Closed-Loop Supply Chain for Chinese Beer Industry, Mathematical Problems in Engineering (2017) 7863202.

[69] Y.-W. Chen, L.-C. Wang, A. Wang, T.-L. Chen, A particle swarm approach for optimizing a multi-stage closed loop supply chain for the solar cell industry, Robotics and ComputerIntegrated Manufacturing 43 (2017) 111-123.

[70] H. Krikke, J. Bloemhof-Ruwaard, L. N. Van Wassenhove, Concurrent product and closed-loop supply chain design with an application to refrigerators, International Journal of Production Research 41 (2003) 3689-3719.

[71] S. K. Srivastava, Network design for reverse logistics, OmegaInternational Journal of Management Science 36 (2008) 535548.

[72] S. Li, N. Wang, T. Jia, Z. He, H. Liang, Multiobjective Optimization for Multiperiod Reverse Logistics Network Design, Ieee Transactions on Engineering Management 63 (2016) 223-
236.

[73] H. Soleimani, M. Seyyed-Esfahani, M. A. Shirazi, A new multi-criteria scenario-based solution approach for stochastic forward/reverse supply chain network design, Annals of Operations Research 242 (2016) 399-421.

[74] M. Zohal, H. Soleimani, Developing an ant colony approach for green closed-loop supply chain network design: a case study in gold industry, Journal of Cleaner Production 133 (2016) 314-337.

[75] A. Hamidieh, B. Naderi, M. Mohammadi, M. Fazli-Khalaf, A robust possibilistic programming model for a responsive closed loop supply chain network design, Cogent Mathematics 4 (2017) 1329886.

[76] P. N. K. Phuc, V. F. Yu, Y.-C. Tsao, Optimizing fuzzy reverse supply chain for end-of-life vehicles, Computers \& Industrial Engineering 113 (2017) 757-765.

[77] E. zceylan, T. Paksoy, T. Bektas, Modeling and optimizing the integrated problem of closed-loop supply chain network design and disassembly line balancing, Transportation Research Part E-Logistics and Transportation Review 61 (2014) $142-164$.

[78] K. Govindan, P. C. Jha, K. Garg, Product recovery optimization in closed-loop supply chain to improve sustainability in manufacturing, International Journal of Production Research 54 (2016) 1463-1486.

[79] L. Q. Dat, D. T. T. Linh, S.-Y. Chou, V. F. Yu, Optimizing reverse logistic costs for recycling end-of-life electrical and electronic products, Expert Systems with Applications 39 (2012) 6380-6387.

[80] S. A. Alumur, I. Tari, Collection Center Location with Equity Considerations in Reverse Logistics Networks, Infor 52 (2014) $157-173$.

[81] W. Chen, B. Kucukyazici, V. Verter, M. Jess Senz, Supply chain design for unlocking the value of remanufacturing under uncertainty, European Journal of Operational Research 247 (2015) 804-819.

[82] S. H. Amin, F. Baki, A facility location model for global closed-loop supply chain network design, Applied Mathematical Modelling 41 (2017) 316-330.

[83] G. Tuzkaya, B. Gulsun, S. Onsel, A methodology for the strategic design of reverse logistics networks and its application in the Turkish white goods industry, International Journal of Production Research 49 (2011) 4543-4571.

[84] J.-E. Lee, K.-D. Lee, Integrated Forward and Reverse Logistics Model: A Case Study in Distilling and Sale Company in Korea, International Journal of Innovative Computing Information and Control 8 (2012) 4483-4495. 
[85] R. Accorsi, R. Manzini, C. Pini, S. Penazzi, On the design of closed-loop networks for product life cycle management: Economic, environmental and geography considerations, Journal of Transport Geography 48 (2015) 121-134.

[86] E. Demirel, N. Demirel, H. Gokcen, A mixed integer linear programming model to optimize reverse logistics activities of end-of-life vehicles in Turkey, Journal of Cleaner Production 112 (2016) 2101-2113.

[87] R. Dubey, A. Gunasekaran, S. J. Childe, The design of a responsive sustainable supply chain network under uncertainty, International Journal of Advanced Manufacturing Technology 80 (2015) 427-445.

[88] A. I. Barros, R. Dekker, V. Scholten, A two-level network for recycling sand: A case study, European Journal of Operational Research 110 (1998) 199-214.

[89] F. Schultmann, B. Engels, O. Rentz, Closed-loop supply chains for spent batteries, Interfaces 33 (2003) 57-71.

[90] B. Mota, M. I. Gomes, A. Carvalho, A. P. Barbosa-Povoa, Towards supply chain sustainability: economic, environmental and social design and planning, Journal of Cleaner Production 105 (2015) 14-27.

[91] K. Subulan, A. S. Tasan, A. Baykasoglu, Designing an environmentally conscious tire closed-loop supply chain network with multiple recovery options using interactive fuzzy goal programming, Applied Mathematical Modelling 39 (2015) 2661-2702.

[92] K. Subulan, A. Baykasoglu, F. B. Ozsoydan, A. S. Tasan, H. Selim, A case-oriented approach to a lead/acid battery closed-loop supply chain network design under risk and uncertainty, Journal of Manufacturing Systems 37 (2015) 340-361.

[93] M. I. Gomes Salema, A. P. Barbosa Povoa, A. Q. Novais, A strategic and tactical model for closed-loop supply chains, Or Spectrum 31 (2009) 573-599.

[94] R. K. Pati, P. Vrat, P. Kumar, A goal programming model for paper recycling systern, Omega-International Journal of Management Science 36 (2008) 405-417.

[95] X. Zhou, Y. Zhou, Designing a multi-echelon reverse logistics operation and network: A case study of office paper in Beijing, Resources Conservation and Recycling 100 (2015) 58-69.

[96] A. Chaabane, A. Ramudhin, M. Paquet, Design of sustainable supply chains under the emission trading scheme, International Journal of Production Economics 135 (2012) 37-49.

[97] B. Vahdani, R. Tavakkoli-Moghaddam, M. Modarres, A. Baboli, Reliable design of a forward/reverse logistics network under uncertainty: A robust-M/M/c queuing model, Transportation Research Part E-Logistics and Transportation Review 48 (2012) 1152-1168.
[98] B. Vahdani, M. Naderi-Beni, A mathematical programming model for recycling network design under uncertainty: an interval-stochastic robust optimization model, International Journal of Advanced Manufacturing Technology 73 (2014) 1057-1071.

[99] P. Mitropoulos, I. Giannikos, I. Mitropoulos, E. Adamides, Developing an integrated solid waste management system in western Greece: a dynamic location analysis, International Transactions in Operational Research 16 (2009) 391-407.

[100] C. Dai, Y. P. Li, G. H. Huang, A two-stage support-vectorregression optimization model for municipal solid waste management - A case study of Beijing, China, Journal of Environmental Management 92 (2011) 3023-3037.

[101] F. Samanlioglu, A multi-objective mathematical model for the industrial hazardous waste location-routing problem, European Journal of Operational Research 226 (2013) 332-340.

[102] W. P. Q. Ng, H. L. Lam, P. S. Varbanov, J. J. Klemes, Waste-to-Energy (WTE) network synthesis for Municipal Solid Waste (MSW), Energy Conversion and Management 85 (2014) 866-874.

[103] K. Govindan, P. Paam, A.-R. Abtahi, A fuzzy multi-objective optimization model for sustainable reverse logistics network design, Ecological Indicators 67 (2016) 753-768.

[104] H. Yu, W. D. Solvang, A general reverse logistics network design model for product reuse and recycling with environmental considerations, International Journal of Advanced Manufacturing Technology 87 (2016) 2693-2711.

[105] H. Yu, W. D. Solvang, A carbon-constrained stochastic optimization model with augmented multi-criteria scenario-based risk-averse solution for reverse logistics network design under uncertainty, Journal of Cleaner Production 164 (2017) 12481267.

[106] A. Banasik, A. Kanellopoulos, G. D. H. Claassen, J. M. Bloemhof-Ruwaard, J. G. A. J. van der Vorst, Closing loops in agricultural supply chains using multi-objective optimization: A case study of an industrial mushroom supply chain, International Journal of Production Economics 183 (2017) 409-420.

[107] The European Parliament and the Council of the European Union, Directive 2008/98/EC of the European Parliamant and of the Council of 19 November 2008 on waste and repealing certain Directives, 2008.

[108] M. I. Gomes Salema, A. P. Barbosa-Povoa, A. Q. Novais, An optimization model for the design of a capacitated multiproduct reverse logistics network with uncertainty, European Journal of Operational Research 179 (2007) 1063-1077.

[109] K. Lieckens, N. Vandaele, Reverse logistics network design with stochastic lead times, Computers \& Operations Research 
34 (2007) 395-416.

[110] UNEP (Ed.), Metal recycling: opportunities, limits, infrastructure: this is report $2 \mathrm{~b}$ of the Global Metal Flows Working Group of the International Resource Panel of UNEP, United Nations Environment Programme, Nairobi, Kenya, 2013.

[111] E. Worrell, M. A. Reuter (Eds.), Handbook of recycling: state-of-the-art for practitioners, analysts, and scientists, Elsevier, Amsterdam, 2014.

[112] M. S. Pishvaee, J. Razmi, Environmental supply chain network design using multi-objective fuzzy mathematical programming, Applied Mathematical Modelling 36 (2012) 34333446.

[113] M. S. Pishvaee, J. Razmi, S. A. Torabi, An accelerated Benders decomposition algorithm for sustainable supply chain network design under uncertainty: A case study of medical needle and syringe supply chain, Transportation Research Part E-Logistics and Transportation Review 67 (2014) 14-38.

[114] G. L. Ferri, G. d. L. Diniz Chaves, G. M. Ribeiro, Reverse logistics network for municipal solid waste management: The inclusion of waste pickers as a Brazilian legal requirement, Waste Management 40 (2015) 173-191.

[115] A. Massarutto, Economic aspects of thermal treatment of solid waste in a sustainable WM system, Waste Management (2014).

[116] European Commission, Reference Document on the Best Available Techniques for Waste Incineration, 2006. URL: http://eippcb.jrc.ec. europa.eu/reference/BREF/wi_ bref_0806.pdf.

[117] Ecluse, ECLUSE Steam Network, 2017. URL: http://www. energiecluster.be/steam-network/.

[118] N. Aras, A. Korugan, G. Buyukozkan, F. S. Serifoglu, I. Erol, M. N. Velioglu, Locating recycling facilities for IT-based electronic waste in Turkey, Journal of Cleaner Production 105 (2015) 324-336.

[119] J. Zhao, V. Verter, A bi-objective model for the used oil location-routing problem, Computers \& Operations Research 62 (2015) 157-168.

[120] M. Zhalechian, R. Tavakkoli-Moghaddam, B. Zahiri, M. Mohammadi, Sustainable design of a closed-loop locationrouting-inventory supply chain network under mixed uncertainty, Transportation Research Part E-Logistics and Transportation Review 89 (2016) 182-214.

[121] A. M. Harijani, S. Mansour, B. Karimi, A multi-objective model for sustainable recycling of municipal solid waste, Waste Management \& Research 35 (2017) 387-399.

[122] J. Mar-Ortiz, B. Adenso-Diaz, J. L. Gonzalez-Velarde, Design of a recovery network for WEEE, collection: the case of
Galicia, Spain, Journal of the Operational Research Society 62 (2011) 1471-1484.

[123] M. A. Kalaitzidou, P. Longinidis, M. C. Georgiadis, Optimal design of closed-loop supply chain networks with multifunctional nodes, Computers \& Chemical Engineering 80 (2015) 73-91.

[124] S. R. Cardoso, A. P. Barbosa-Povoa, S. Relvas, Integrating financial risk measures into the design and planning of closedloop supply chains, Computers \& Chemical Engineering 85 (2016) 105-123.

[125] E. Keyvanshokooh, S. M. Ryan, E. Kabir, Hybrid robust and stochastic optimization for closed-loop supply chain network design using accelerated Benders decomposition, European Journal of Operational Research 249 (2016) 76-92.

[126] J. D. Darbari, V. Agarwal, V. S. S. Yadavalli, D. Galar, P. C. Jha, A multi-objective fuzzy mathematical approach for sustainable reverse supply chain configuration, Journal of Transport and Supply Chain Management 11 (2017) a267.

[127] S. Keivanpour, D. A. Kadi, C. Mascle, End-of-life aircraft treatment in the context of sustainable development, lean management, and global business, International Journal of Sustainable Transportation 11 (2017) 357-380.

[128] H. Uster, S. O. Hwang, Closed-Loop Supply Chain Network Design Under Demand and Return Uncertainty, Transportation Science 51 (2017) 1063-1085.

[129] M. C. Fonseca, A. Garcia-Sanchez, M. Ortega-Mier, F. Saldanha-da Gama, A stochastic bi-objective location model for strategic reverse logistics, Top 18 (2010) 158-184.

[130] H. Asefi, S. Lim, M. Maghrebi, A mathematical model for the municipal solid waste location-routing problem with intermediate transfer stations, Australasian Journal of Information Systems 19 (2015) S21-S35.

[131] N. Tokhmehchi, A. Makui, S. Sadi-Nezhad, A Hybrid Approach to Solve a Model of Closed-Loop Supply Chain, Mathematical Problems in Engineering (2015) 179102.

[132] A. D. Diaz-Barriga-Fernandez, J. E. Santibanez-Aguilar, N. Radwan, F. Napoles-Rivera, M. M. El-Halwagi, J. M. Ponce-Ortega, Strategic Planning for Managing Municipal Solid Wastes with Consideration of Multiple Stakeholders, Acs Sustainable Chemistry \& Engineering 5 (2017) 1074410762.

[133] A. M. Harijani, S. Mansour, B. Karimi, C.-G. Lee, Multiperiod sustainable and integrated recycling network for municipal solid waste - A case study in Tehran, Journal of Cleaner Production 151 (2017) 96-108.

[134] A. M. Sampat, E. Martin, M. Martin, V. M. Zavala, Optimization formulations for multi-product supply chain net- 
works, Computers \& Chemical Engineering 104 (2017) 296310 .

[135] S. Shokohyar, S. Mansour, Simulation-based optimisation of a sustainable recovery network for Waste from Electrical and Electronic Equipment (WEEE), International Journal of Computer Integrated Manufacturing 26 (2013) 487-503.

[136] B. M. Beamon, C. Fernandes, Supply-chain network configuration for product recovery, Production Planning \& Control 15 (2004) 270-281

[137] Fost Plus, Proefproject P+MD in Aalter, 2015. URL: https: //www.fostplus.be/nl/proefproject-aalter.

[138] M. I. Gomes, A. P. Barbosa-Povoa, A. Q. Novais, Modelling a recovery network for WEEE: A case study in Portugal, Waste Management 31 (2011) 1645-1660.

[139] T. Assavapokee, W. Wongthatsanekorn, Reverse production system infrastructure design for electronic products in the state of Texas, Computers \& Industrial Engineering 62 (2012) 129-140.

[140] B. Fahimnia, J. Sarkis, F. Dehghanian, N. Banihashemi, S. Rahman, The impact of carbon pricing on a closed-loop supply chain: an Australian case study, Journal of Cleaner Production 59 (2013) 210-225.

[141] M. Faccio, A. Persona, F. Sgarbossa, G. Zanin, Sustainable $\mathrm{SC}$ through the complete reprocessing of end-of-life products by manufacturers: A traditional versus social responsibility company perspective, European Journal of Operational Research 233 (2014) 359-373.

[142] M. Ramezani, A. M. Kimiagari, B. Karimi, T. H. Hejazi, Closed-loop supply chain network design under a fuzzy environment, Knowledge-Based Systems 59 (2014) 108-120.

[143] L. J. Zeballos, C. A. Mendez, A. P. Barbosa-Povoa, A. Q. Novais, Multi-period design and planning of closed-loop supply chains with uncertain supply and demand, Computers \& Chemical Engineering 66 (2014) 151-164.

[144] B. Vahdani, An Optimization Model for Multi-Objective Closed-Loop Supply Chain Network Under Uncertainty: A Hybrid Fuzzy-Stochastic Programming Method, Iranian Journal of Fuzzy Systems 12 (2015) 33-57.

[145] Z. Dai, Multi-objective fuzzy design of closed-loop supply chain network considering risks and environmental impact, Human and Ecological Risk Assessment 22 (2016) 845-873.

[146] J. Djikanovic, M. Vujosevic, A new integrated forward and reverse logistics model: A case study, International Journal of Computational Intelligence Systems 9 (2016) 25-35.

[147] A. Entezaminia, M. Heydari, D. Rahmani, A multi-objective model for multi-product multi-site aggregate production planning in a green supply chain: Considering collection and re- cycling centers, Journal of Manufacturing Systems 40 (2016) $63-75$.

[148] L. J. Zeballos, C. A. Mendez, A. P. Barbosa-Povoa, Design and Planning of Closed-Loop Supply Chains: A Risk-Averse Multistage Stochastic Approach, Industrial \& Engineering Chemistry Research 55 (2016) 6236-6249.

[149] N. Asgari, M. Rajabi, M. Jamshidi, M. Khatami, R. Z. Farahani, A memetic algorithm for a multi-objective obnoxious waste location-routing problem: a case study, Annals of Operations Research 250 (2017) 279-308.

[150] A. Entezaminia, M. Heidari, D. Rahmani, Robust aggregate production planning in a green supply chain under uncertainty considering reverse logistics: a case study, International Journal of Advanced Manufacturing Technology 90 (2017) 1507-1528

[151] M. Feito-Cespon, W. Sarache, F. Piedra-Jimenez, R. CesponCastro, Redesign of a sustainable reverse supply chain under uncertainty: A case study, Journal of Cleaner Production 151 (2017) 206-217.

[152] F. Mohammed, S. Z. Selim, A. Hassan, M. N. Syed, Multiperiod planning of closed-loop supply chain with carbon policies under uncertainty, Transportation Research Part DTransport and Environment 51 (2017) 146-172.

[153] Z. Xu, S. Pokharel, A. Elomri, F. Mutlu, Emission policies and their analysis for the design of hybrid and dedicated closed-loop supply chains, Journal of Cleaner Production 142 (2017) 4152-4168.

[154] A. Mohajeri, M. Fallah, A carbon footprint-based closed-loop supply chain model under uncertainty with risk analysis: A case study, Transportation Research Part D-Transport and Environment 48 (2016) 425-450.

[155] B. Vahdani, J. Razmi, R. Tavakkoli-Moghaddam, Fuzzy Possibilistic Modeling for Closed Loop Recycling Collection Networks, Environmental Modeling \& Assessment 17 (2012) 623637.

[156] J. N. de Figueiredo, S. F. Mayerle, Designing minimumcost recycling collection networks with required throughput, Transportation Research Part E-Logistics and Transportation Review 44 (2008) 731-752.

[157] M. I. Gomes Salema, A. P. Barbosa-Povoa, A. Q. Novais, Simultaneous design and planning of supply chains with reverse flows: A generic modelling framework, European Journal of Operational Research 203 (2010) 336-349.

[158] L. J. Zeballos, M. I. Gomes, A. P. Barbosa-Povoa, A. Q. Novais, Addressing the uncertain quality and quantity of returns in closed-loop supply chains, Computers \& Chemical Engineering 47 (2012) 237-247. 
[159] E. zceylan, T. Paksoy, A mixed integer programming model for a closed-loop supply-chain network, International Journal of Production Research 51 (2013) 718-734.

[160] H. S. Kilic, U. Cebeci, M. B. Ayhan, Reverse logistics system design for the waste of electrical and electronic equipment (WEEE) in Turkey, Resources Conservation and Recycling 95 (2015) 120-132.

[161] M. Jeihoonian, M. K. Zanjani, M. Gendreau, Accelerating Benders decomposition for closed-loop supply chain network design: Case of used durable products with different quality levels, European Journal of Operational Research 251 (2016) 830-845.

[162] P. Yi, M. Huang, L. Guo, T. Shi, A retailer oriented closedloop supply chain network design for end of life construction machinery remanufacturing, Journal of Cleaner Production 124 (2016) 191-203.

[163] M. Zarei, S. Mansour, A. H. Kashan, B. Karimi, Designing a Reverse Logistics Network for End-of-Life Vehicles Recovery, Mathematical Problems in Engineering (2010) 649028.

[164] V. De Rosa, M. Gebhard, E. Hartmann, J. Wollenweber, Robust sustainable bi-directional logistics network design under uncertainty, International Journal of Production Economics 145 (2013) 184-198.

[165] E. A. V. Toso, D. Alem, Effective location models for sorting recyclables in public management, European Journal of Operational Research 234 (2014) 839-860.

[166] S. Rezapour, R. Z. Farahani, B. Fahimnia, K. Govindan, Y. Mansouri, Competitive closed-loop supply chain network design with price-dependent demands, Journal of Cleaner Production 93 (2015) 251-272.

[167] M. Fattahi, K. Govindan, Integrated forward/reverse logistics network design under uncertainty with pricing for collection of used products, Annals of Operations Research 253 (2017) $193-225$.

[168] A. Hasani, S. H. Zegordi, E. Nikbakhsh, Robust closed-loop supply chain network design for perishable goods in agile manufacturing under uncertainty, International Journal of Production Research 50 (2012) 4649-4669.

[169] S. H. Amin, G. Zhang, A multi-objective facility location model for closed-loop supply chain network under uncertain demand and return, Applied Mathematical Modelling 37 (2013) 4165-4176.

[170] Y. T. Chen, F. T. S. Chan, S. H. Chung, An integrated closed-loop supply chain model with location allocation problem and product recycling decisions, International Journal of Production Research 53 (2015) 3120-3140.

[171] K. M. M. Sheriff, S. Nachiappan, H. Min, Combined location and routing problems for designing the quality-dependent and multi-product reverse logistics network, Journal of the Operational Research Society 65 (2014) 873-887.

[172] K. S. Moghaddam, Fuzzy multi-objective model for supplier selection and order allocation in reverse logistics systems under supply and demand uncertainty, Expert Systems with Applications 42 (2015) 6237-6254.

[173] K. S. Moghaddam, Supplier selection and order allocation in closed-loop supply chain systems using hybrid Monte Carlo simulation and goal programming, International Journal of Production Research 53 (2015) 6320-6338.

[174] N. Chang, S. Wang, A Locational Model for the Site Selection of Solid-Waste Management Facilities with Traffic Congestion Constraints, Civil Engineering Systems 11 (1995) 287-306.

[175] K. J. Brothers, P. J. Krantz, L. E. McClannahan, Office paper recycling: A function of container proximity, Journal of Applied Behavior Analysis 27 (1994) 153-160.

[176] R. T. O'Connor, D. C. Lerman, J. N. Fritz, H. B. Hodde, Effects of Number and Location of Bins on Plastic Recycling at a University, Journal of Applied Behavior Analysis; Malden 43 (2010) 711-5.

[177] WRAP, Analysis of kerbside dry recycling performance in England 2007/08 (WRAP Project EVA034-087), 2009.

[178] M. Vidovic, B. Dimitrijevic, B. Ratkovic, V. Simic, A novel covering approach to positioning ELV collection points, Resources Conservation and Recycling 57 (2011) 1-9.

[179] K. Subulan, A. S. Tasan, A. Baykasoglu, A fuzzy goal programming model to strategic planning problem of a lead/acid battery closed-loop supply chain, Journal of Manufacturing Systems 37 (2015) 243-264.

[180] C. Wu, D. Barnes, Partner selection for reverse logistics centres in green supply chains: a fuzzy artificial immune optimisation approach, Production Planning \& Control 27 (2016) 1356-1372.

[181] X. Wang, J. Qiu, T. Li, J. Ruan, A Network Optimization Research for Product Returns Using Modified Plant Growth Simulation Algorithm, Scientific Programming (2017) 1080468.

[182] M. Ramezani, M. Bashiri, R. Tavakkoli-Moghaddam, A new multi-objective stochastic model for a forward/reverse logistic network design with responsiveness and quality level, Applied Mathematical Modelling 37 (2013) 328-344.

[183] M. Ramezani, M. Bashiri, R. Tavakkoli-Moghaddam, A robust design for a closed-loop supply chain network under an uncertain environment, International Journal of Advanced Manufacturing Technology 66 (2013) 825-843.

[184] N. Demirel, E. zceylan, T. Paksoy, H. Gokcen, A genetic 
algorithm approach for optimising a closed-loop supply chain network with crisp and fuzzy objectives, International Journal of Production Research 52 (2014) 3637-3664.

[185] A. Choudhary, S. Sarkar, S. Settur, M. K. Tiwari, A carbon market sensitive optimization model for integrated forwardreverse logistics, International Journal of Production Economics 164 (2015) 433-444.

[186] H. Soleimani, K. Govindan, H. Saghafi, H. Jafari, Fuzzy multi-objective sustainable and green closed-loop supply chain network design, Computers \& Industrial Engineering 109 (2017) 191-203.

[187] Z. Xu, A. Elomri, S. Pokharel, Q. Zhang, X. G. Ming, W. Liu, Global reverse supply chain design for solid waste recycling under uncertainties and carbon emission constraint, Waste Management 64 (2017) 358-370.

[188] N. B. Chang, Y. L. Wei, Strategic planning of recycling dropoff stations and collection network by multiobjective programming, Environmental Management 24 (1999) 247-263.

[189] N. B. Chang, Y. L. Wei, Siting recycling drop-off stations in urban area by genetic algorithm-based fuzzy multiobjective nonlinear integer programming modeling, Fuzzy Sets and Systems 114 (2000) 133-149.

[190] M. S. Pishvaee, S. A. Torabi, A possibilistic programming approach for closed-loop supply chain network design under uncertainty, Fuzzy Sets and Systems 161 (2010) 2668-2683.

[191] M. Eskandarpour, S. H. Zegordi, E. Nikbakhsh, A parallel variable neighborhood search for the multi-objective sustainable post-sales network design problem, International Journal of Production Economics 145 (2013) 117-131.

[192] A. Jindal, K. S. Sangwan, Multi-objective fuzzy mathematical modelling of closed-loop supply chain considering economical and environmental factors, Annals of Operations Research 257 (2017) 95-120.

[193] R. Ma, L. Yao, M. Jin, P. Ren, Z. Lv, Robust environmental closed-loop supply chain design under uncertainty, Chaos Solitons \& Fractals 89 (2016) 195-202.

[194] L. Ameknassi, D. Ait-Kadi, N. Rezg, Integration of logistics outsourcing decisions in a green supply chain design: A stochastic multi-objective multi-period multi-product programming model, International Journal of Production Economics 182 (2016) 165-184.

[195] J. Rakas, D. Teodorovic, T. Kim, Multi-objective modeling for determining location of undesirable facilities, Transportation Research Part D-Transport and Environment 9 (2004) 125-138.

[196] A. L. Medaglia, J. G. Villegas, D. M. Rodriguez-Coca, Hybrid biobjective evolutionary algorithms for the design of a hospital waste management network, Journal of Heuristics 15 (2009) 153-176.

[197] S. H. Amin, G. Zhang, A three-stage model for closed-loop supply chain configuration under uncertainty, International Journal of Production Research 51 (2013) 1405-1425.

[198] P. Bhave, K. Sadhwani, Solid Waste Management Legislation - A Review, Environmental Policy and Law 46 (2016) 168.

[199] B. Ayvaz, B. Bolat, N. Aydin, Stochastic reverse logistics network design for waste of electrical and electronic equipment, Resources Conservation and Recycling 104 (2015) 391-404.

[200] J. Xu, P. Wei, A bi-level model for location-allocation problem of construction \& demolition waste management under fuzzy random environment, International Journal of Civil Engineering 10 (2012) 1-12.

[201] P. N. K. Phuc, V. F. Yu, S.-Y. Chou, Optimizing the Fuzzy Closed-Loop Supply Chain for Electrical and Electronic Equipments, International Journal of Fuzzy Systems 15 (2013) 9-21.

[202] A. Jindal, K. S. Sangwan, Closed loop supply chain network design and optimisation using fuzzy mixed integer linear programming model, International Journal of Production Research 52 (2014) 4156-4173.

[203] M. S. Pishvaee, M. Rabbani, S. A. Torabi, A robust optimization approach to closed-loop supply chain network design under uncertainty, Applied Mathematical Modelling 35 (2011) $637-649$.

[204] M. S. Kisomi, M. Solimanpur, A. Doniavi, An integrated supply chain configuration model and procurement management under uncertainty: A set-based robust optimization methodology, Applied Mathematical Modelling 40 (2016) 7928-7947.

[205] B. Vahdani, R. Tavakkoli-Moghaddam, F. Jolai, A. Baboli, Reliable design of a closed loop supply chain network under uncertainty: An interval fuzzy possibilistic chanceconstrained model, Engineering Optimization 45 (2013) 745765.

[206] S. M. Hatefi, F. Jolai, S. A. Torabi, R. Tavakkoli-Moghaddam, A credibility-constrained programming for reliable forwardreverse logistics network design under uncertainty and facility disruptions, International Journal of Computer Integrated Manufacturing 28 (2015) 664-678.

[207] G. T. Temur, S. Yanik, A Novel Approach for Multi-Period Reverse Logistics Network Design under High Uncertainty, International Journal of Computational Intelligence Systems 10 (2017) 1168-1185.

[208] S. Ene, N. ztrk, Network modeling for reverse flows of endof-life vehicles, Waste Management 38 (2015) 284-296.

[209] Z. Dai, H.-m. Dai, Bi-objective closed-loop supply chain net- 
work design with risks in a fuzzy environment, Journal of Industrial and Production Engineering 33 (2016) 169-180.

[210] M. Talaei, B. F. Moghaddam, M. S. Pishvaee, A. BozorgiAmiri, S. Gholamnejad, A robust fuzzy optimization model for carbon-efficient closed-loop supply chain network design problem: a numerical illustration in electronics industry, Journal of Cleaner Production 113 (2016) 662-673.

[211] S. M. Hatefi, F. Jolai, S. A. Torabi, R. Tavakkoli-Moghaddam, Integrated forward-reverse logistics network design under uncertainty and reliability consideration, Scientia Iranica 23 (2016) 721-735.

[212] V. zkr, H. Baslgl, Multi-objective optimization of closed-loop supply chains in uncertain environment, Journal of Cleaner Production 41 (2013) 114-125.

[213] H. Soleimani, K. Govindan, Reverse logistics network design and planning utilizing conditional value at risk, European Journal of Operational Research 237 (2014) 487-497.

[214] H. Yu, W. D. Solvang, A Stochastic Programming Approach with Improved Multi-Criteria Scenario-Based Solution Method for Sustainable Reverse Logistics Design of Waste Electrical and Electronic Equipment (WEEE), Sustainability 8 (2016) 1331.

[215] Z. Dai, Z. Li, Design of a dynamic closed-loop supply chain network using fuzzy bi-objective linear programming approach, Journal of Industrial and Production Engineering 34 (2017) 330-343.

[216] E. Ozceylan, Simultaneous optimization of closed- and openloop supply chain networks with common components, Journal of Manufacturing Systems 41 (2016) 143-156.

[217] M. Keshavarz Ghorabaee, M. Amiri, L. Olfat, S. M. A. Khatami Firouzabadi, Designing a Multi-Product MultiPeriod Supply Chain Network with Reverse Logistics and Multiple Objectives Under Uncertainty, Technological and Economic Development of Economy 23 (2017) 520-548.

[218] I.-H. Hong, T. Assavapokee, J. Ammons, C. Boelkins, K. Gilliam, D. Oudit, M. J. Realff, J. M. Vannicola, W. Wongthatsanekorn, Planning the e-scrap reverse production system under uncertainty in the state of Georgia: A case study, Ieee Transactions on Electronics Packaging Manufacturing 29 (2006) 150-162.

[219] M. Jeihoonian, M. K. Zanjani, M. Gendreau, Closed-loop supply chain network design under uncertain quality status: Case of durable products, International Journal of Production Economics 183 (2017) 470-486.

[220] A. Pedram, N. Bin Yusoff, O. E. Udoncy, A. B. Mahat, P. Pedram, A. Babalola, Integrated forward and reverse supply chain: A tire case study, Waste Management 60 (2017) 460-
470.

[221] S. M. Hatefi, F. Jolai, Robust and reliable forward-reverse logistics network design under demand uncertainty and facility disruptions, Applied Mathematical Modelling 38 (2014) 2630-2647.

[222] S. Qiang, X.-Z. Zhou, Robust reverse logistics network design for the waste of electrical and electronic equipment (WEEE) under recovery uncertainty, Journal of Environmental Biology 37 (2016) 1153-1165.

[223] K. Lieckens, N. Vandaele, Multi-level reverse logistics network design under uncertainty, International Journal of Production Research 50 (2012) 23-40.

[224] B. Vahdani, M. Mohammadi, A bi-objective intervalstochastic robust optimization model for designing closed loop supply chain network with multi-priority queuing system, International Journal of Production Economics 170 (2015) 6787.

[225] S. S. Kara, S. Onut, A stochastic optimization approach for paper recycling reverse logistics network design under uncertainty, International Journal of Environmental Science and Technology 7 (2010) 717-730.

[226] I. Litvinchev, Y. A. Rios, D. Ozdemir, L. G. HernandezLanda, Multiperiod and stochastic formulations for a closed loop supply chain with incentives, Journal of Computer and Systems Sciences International 53 (2014) 201-211.

[227] S. R. Cardoso, A. P. F. D. Barbosa-Povoa, S. Relvas, Design and planning of supply chains with integration of reverse logistics activities under demand uncertainty, European Journal of Operational Research 226 (2013) 436-451.

[228] E. zceylan, T. Paksoy, Fuzzy multi-objective linear programming approach for optimising a closed-loop supply chain network, International Journal of Production Research 51 (2013) 2443-2461.

[229] A. Mirakhorli, Fuzzy multi-objective optimization for closed loop logistics network design in bread-producing industries, International Journal of Advanced Manufacturing Technology 70 (2014) 349-362.

[230] S. J. Sadjadi, R. Soltani, A. Eskandarpour, Location based treatment activities for end of life products network design under uncertainty by a robust multi-objective memetic-based heuristic approach, Applied Soft Computing 23 (2014) 215226.

[231] P. G. Berglund, C. Kwon, Robust Facility Location Problem for Hazardous Waste Transportation, Networks \& Spatial Economics 14 (2014) 91-116.

[232] M. Ramezani, A. M. Kimiagari, B. Karimi, Interrelating physical and financial flows in a bi-objective closed-loop supply 
chain network problem with uncertainty, Scientia Iranica 22 (2015) 1278-1293.

[233] C. K. M. Lee, T. M. Chan, Development of RFID-based Reverse Logistics System, Expert Systems with Applications 36 (2009) 9299-9307.

[234] H.-F. Wang, H.-W. Hsu, A closed-loop logistic model with a spanning-tree based genetic algorithm, Computers \& Operations Research 37 (2010) 376-389.

[235] A. Diabat, D. Kannan, M. Kaliyan, D. Svetinovic, An optimization model for product returns using genetic algorithms and artificial immune system, Resources Conservation and Recycling 74 (2013) 156-169.

[236] B. Golebiewski, J. Trajer, M. Jaros, R. Winiczenko, Modelling of the location of vehicle recycling facilities: A case study in Poland, Resources Conservation and Recycling 80 (2013) 1020.

[237] B. D. Song, J. R. Morrison, Y. D. Ko, Efficient location and allocation strategies for undesirable facilities considering their fundamental properties, Computers \& Industrial Engineering 65 (2013) 475-484.

[238] E. Roghanian, P. Pazhoheshfar, An optimization model for reverse logistics network under stochastic environment by using genetic algorithm, Journal of Manufacturing Systems 33 (2014) 348-356.

[239] H. Soleimani, G. Kannan, A hybrid particle swarm optimization and genetic algorithm for closed-loop supply chain network design in large-scale networks, Applied Mathematical Modelling 39 (2015) 3990-4012.

[240] Z. Wang, H. Soleimani, D. Kannan, L. Xu, Advanced crossentropy in closed-loop supply chain planning, Journal of Cleaner Production 135 (2016) 201-213.

[241] J. Shi, Z. Liu, L. Tang, J. Xiong, Multi-objective optimization for a closed-loop network design problem using an improved genetic algorithm, Applied Mathematical Modelling 45 (2017) $14-30$.

[242] X.-c. Zhou, Z.-x. Zhao, K.-j. Zhou, C.-h. He, Remanufacturing closed-loop supply chain network design based on genetic particle swarm optimization algorithm, Journal of Central South University of Technology 19 (2012) 482-487.

[243] P. Fu, H. Li, X. Wang, J. Luo, S.-l. Zhan, C. Zuo, Multiobjective Location Model Design Based on Government Subsidy in the Recycling of CDW, Mathematical Problems in Engineering (2017) 9081628.

[244] P. Subramanian, N. Ramkumar, T. T. Narendran, K. Ganesh, PRISM: PRIority based SiMulated annealing for a closed loop supply chain network design problem, Applied Soft Computing 13 (2013) 1121-1135.
[245] X. Chen, T. Fujita, Y. Hayashi, H. Kato, Y. Geng, Determining optimal resource recycling boundary at regional level: A case study on Tokyo Metropolitan Area in Japan, European Journal of Operational Research 233 (2014) 337-348.

[246] K. Sahyouni, R. C. Savaskan, A facility location model for bidirectional flows, Transportation Science 41 (2007) 484-499.

[247] P. F. Vieira, S. M. Vieira, M. I. Gomes, A. P. Barbosa-Povoa, J. M. C. Sousa, Designing closed-loop supply chains with nonlinear dimensioning factors using ant colony optimization, Soft Computing 19 (2015) 2245-2264.

[248] S. Saranwong, C. Likasiri, Product distribution via a bi-level programming approach: Algorithms and a case study in municipal waste system, Expert Systems with Applications 44 (2016) 78-91.

[249] S. R. Mirmajlesi, R. Shafaei, An integrated approach to solve a robust forward/reverse supply chain for short lifetime products, Computers \& Industrial Engineering 97 (2016) 222-239.

[250] Department for Environment, Food and Rural Affairs, Economies of Scale - Waste Management Optimisation Study by AEA Technology, 2007. URL: http://www.persona.uk. com/barnfield/Core_docs/J/J9.pdf.

[251] Department for Environment, Food and Rural Affairs, Incineration of Municipal Solid Waste, Technical Report, Department for Environment, Food \& Rural Affairs, 2013.

[252] X. Wang, G. Gaustad, C. W. Babbitt, K. Richa, Economies of scale for future lithium-ion battery recycling infrastructure, Resources, Conservation and Recycling 83 (2014) 53-62.

[253] T. C. Kinnaman, The economics of municipal solid waste management, Waste Management 29 (2009) 2615-2617.

[254] The Economist, The truth about recycling, The Economist (2007).

[255] X. Bing, J. Bloemhof-Ruwaard, A. Chaabane, J. van der Vorst, Global reverse supply chain redesign for household plastic waste under the emission trading scheme, Journal of Cleaner Production 103 (2015) 28-39.

[256] H. Friege, A. Fendel, Competition of different methods for recovering energy from waste, Waste Management \& Research 29 (2011) S30-S38.

[257] H. Scharff, Landfill reduction experience in The Netherlands, Waste Management 34 (2014) 2218-2224.

[258] L. Yao, W. He, G. Li, J. Huang, The integrated design and optimization of a WEEE collection network in Shanghai, China, Waste Management \& Research 31 (2013) 910-919.

[259] H. M. le Blanc, H. A. Fleuren, H. R. Krikke, Redesign of a recycling system for LPG-tanks, Or Spectrum 26 (2004) 283-304.

[260] K. M. M. Sheriff, N. Subramanian, S. Rahman, J. Jayaram, 
Integrated optimization model and methodology for plastics recycling: Indian empirical evidence, Journal of Cleaner Production 153 (2017) 707-717.

[261] S. Deng, Y. Li, H. Guo, B. Liu, Solving a Closed-Loop Location-Inventory-Routing Problem with Mixed Quality Defects Returns in E-Commerce by Hybrid Ant Colony Optimization Algorithm, Discrete Dynamics in Nature and Society (2016) 6467812.

[262] Q. Yuchi, Z. He, Z. Yang, N. Wang, A Location-InventoryRouting Problem in Forward and Reverse Logistics Network Design, Discrete Dynamics in Nature and Society (2016) 3475369 .

[263] J. Zhao, G. Y. Ke, Incorporating inventory risks in locationrouting models for explosive waste management, International Journal of Production Economics 193 (2017) 123-136.

[264] J. Belin, L. De Boeck, J. Van Ackere, Municipal Solid Waste Collection and Management Problems: A Literature Review, Transportation Science 48 (2014) 78-102.

[265] H. Han, E. Ponce-Cueto, Waste Collection Vehicle Routing Problem: Literature Review, Promet-Traffic \& Transportation 27 (2015) 345-358.

[266] D. T. Kumar, H. Soleimani, G. Kannan, Forecasting Return Products in an Integrated Forward/Reverse Supply Chain Utilizing an Anfis, International Journal of Applied Mathematics and Computer Science 24 (2014) 669-682.

[267] A. A. Syntetos, Z. Babai, J. E. Boylan, S. Kolassa, K. Nikolopoulos, Supply chain forecasting: Theory, practice, their gap and the future, European Journal of Operational Research 252 (2016) 1-26.

[268] P. Beigl, S. Lebersorger, S. Salhofer, Modelling municipal solid waste generation: A review, Waste Management 28 (2008) 200-214.

[269] OECD, Extended Producer Responsibility, Organisation for Economic Co-operation and Development, Paris, 2001. URL: http://www. oecd-ilibrary.org/content/book/ 9789264189867-en.

[270] Canadian Council of Ministers of the Environment, Canadawide Action Plan for Extended Producer Responsibility, 2009.

[271] European Commission - DG Environment, Development of Guidance on Extended Producer Responsibility (EPR) Final Report, 2014.

[272] European Commission, Roadmap to a Resource Efficient Europe, 2011.

[273] United States Environmental Protection Agency, Advancing Resource Efficiency in the Supply Chain Observations and Opportunities for Action, 2016.

[274] D. R. Schneider, A. Ragossnig, Recycling and incineration, contradiction or coexistence?, Waste Management and Research 33 (2015) 693-695.

[275] European Environment Agency, Municipal waste management in Germany, Technical Report, 2013.

[276] A. Bosmans, I. Vanderreydt, D. Geysen, L. Helsen, The crucial role of Waste-to-Energy technologies in enhanced landfill mining: a technology review, Journal of Cleaner Production 55 (2013) 10-23.

[277] A. Genovese, A. A. Acquaye, A. Figueroa, S. L. Koh, Sustainable supply chain management and the transition towards a circular economy: Evidence and some applications, Omega 66 (2017) 344-357.

[278] OECD, Policy Roundtables, Waste Management Services 2013, 2013.

[279] D. Hoornweg, P. Bhada-Tata, What a Waste : A Global Review of Solid Waste Management, 2012.

[280] H. R. Krikke, A. van Harten, P. C. Schuur, Business case Oce: Reverse logistic network re-design for copiers, Or Spektrum 21 (1999) 381-409.

[281] S. Mansour, M. Zarei, A multi-period reverse logistics optimisation model for end-of-life vehicles recovery based on EU Directive, International Journal of Computer Integrated Manufacturing 21 (2008) 764-777.

[282] J.-J. Kao, L.-M. Wen, K.-H. Liu, Service Distance and RatioBased Location-Allocation Models for Siting Recycling Depots, Journal of Environmental Engineering-Asce 136 (2010) 444-450.

[283] B. Galan, E. Dosal, A. Andres, J. Viguri, Optimisation of the construction and demolition waste management facilities location in Cantabria (Spain) under economical and environmental criteria, Waste and Biomass Valorization 4 (2013) 797-808.

[284] J. Zhao, L. Huang, D.-H. Lee, Q. Peng, Improved approaches to the network design problem in regional hazardous waste management systems, Transportation Research Part ELogistics and Transportation Review 88 (2016) 52-75.

[285] J. Li, L. He, X. Fan, Y. Chen, H. Lu, Optimal control of greenhouse gas emissions and system cost for integrated municipal solid waste management with considering a hierarchical structure, Waste Management \& Research 35 (2017) 874-889.

[286] A. Budak, A. Ustundag, Reverse logistics optimisation for waste collection and disposal in health institutions: the case of Turkey, International Journal of Logistics-Research and Applications 20 (2017) 322-341.

[287] A. P. Antunes, Location analysis helps manage solid waste in Central Portugal, Interfaces 29 (1999) 32-43.

[288] C. Chatzouridis, D. Komilis, A methodology to optimally 
site and design municipal solid waste transfer stations using binary programming, Resources, Conservation and Recycling 60 (2012) 89-98.

[289] D. Kannan, A. Diabat, M. Alrefaei, K. Govindan, G. Yong, A carbon footprint based reverse logistics network design model, Resources Conservation and Recycling 67 (2012) 75-79.

[290] Y. Xue, Z. Wen, X. Ji, H. T. A. Bressers, C. Zhang, Location Optimization of Urban Mining Facilities with Maximal Covering Model in GIS, Journal of Industrial Ecology 21 (2017) $913-923$.

[291] E. zceylan, T. Paksoy, Reverse supply chain optimisation with disassembly line balancing, International Journal of Production Research 51 (2013) 5985-6001.

[292] E. Ponce-Cueto, M. Molenat Muelas, Integrating forward and reverse logistics network for commercial goods management. An integer linear programming model proposal, International Journal of Production Management and Engineering 3 (2015) 25-32.

[293] A. Rahmani, Competitive facility location problem with attractiveness adjustment of the follower on the closed supply chain, Cogent Mathematics 3 (2016) 1189375.

[294] S. H. Amin, G. Zhang, A proposed mathematical model for closed-loop network configuration based on product life cycle, International Journal of Advanced Manufacturing Technology 58 (2012) 791-801.

[295] T. Abdallah, A. Diabat, D. Simchi-Levi, Sustainable supply chain design: a closed-loop formulation and sensitivity analysis, Production Planning \& Control 23 (2012) 120-133.

[296] S. H. Amin, G. Zhang, P. Akhtar, Effects of uncertainty on a tire closed-loop supply chain network, Expert Systems with Applications 73 (2017) 82-91.

[297] E. K. F. Coelho, G. R. Mateus, A capacitated plant location model for Reverse Logistics Activities, Journal of Cleaner Production 167 (2017) 1165-1176.

[298] Y. Y. Cui, Z. Guan, U. Saif, L. Zhang, F. Zhang, J. Mirza, Close loop supply chain network problem with uncertainty in demand and returned products: Genetic artificial bee colony algorithm approach, Journal of Cleaner Production 162 (2017) 717-742

[299] M. M. Paydar, V. Babaveisi, A. S. Safaei, An engine oil closedloop supply chain design considering collection risk, Computers \& Chemical Engineering 104 (2017) 38-55.

[300] A. S. Safaei, A. Roozbeh, M. M. Paydar, A robust optimization model for the design of a cardboard closed-loop supply chain, Journal of Cleaner Production 166 (2017) 1154-1168.

[301] H. Lee, T. Zhang, M. Boile, S. Theofanis, S. Choo, Designing an integrated logistics network in a supply chain system,
KSCE Journal of Civil Engineering 17 (2013) 806-814.

[302] V. zkr, H. Baslgl, Modelling product-recovery processes in closed-loop supply-chain network design, International Journal of Production Research 50 (2012) 2218-2233.

[303] T. Assavapokee, M. J. Realff, J. C. Ammons, I.-H. Hong, Scenario relaxation algorithm for finite scenario-based minmax regret and minmax relative regret robust optimization, Computers \& Operations Research 35 (2008) 2093-2102. 